\title{
UNIWERSYTET JAGIELLOŃSKI
}

KRAKÓW

WydZIAE FIZYKI, Astronomi

I INFORMATYKI STOSOWANEJ

InSTYTUT FIZYKI IM. MARIANA SMOLUCHOWSKIEGO

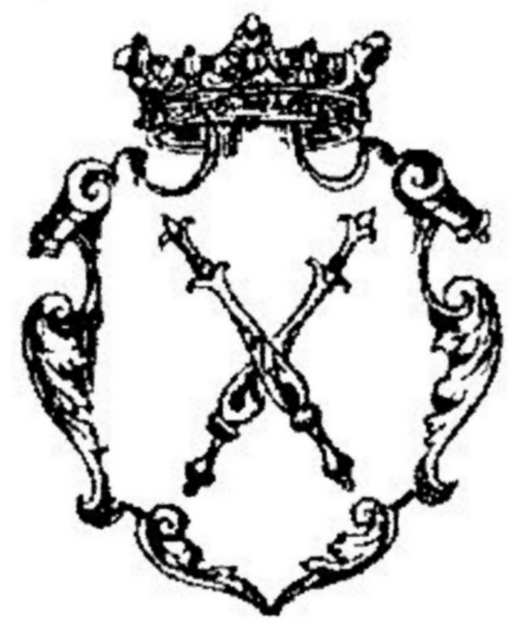

\section{Warunki pełnej synchronizacji w uogólnionych modelach Kuramoto}

\author{
Jeremi Ochab \\ Praca magisterska
}

Promotor: dr hab. Paweł F. Góra

KRAKÓW 2009 



\section{Spis treści}

$\begin{array}{lc}\text { Wstęp } & 3\end{array}$

0.1 Model Kuramoto . . . . . . . . . . . . . . . . . . . . . . 4

0.2 Sprzężenie lokalne w modelu Kuramoto . . . . . . . . . . . . . . . . 6

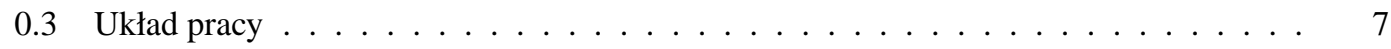

1 Lokalny, jednowymiarowy model Kuramoto $\quad 8$

1.1 Znajdywanie rozwiązań zsynchronizowanych . . . . . . . . . . . . . . 10

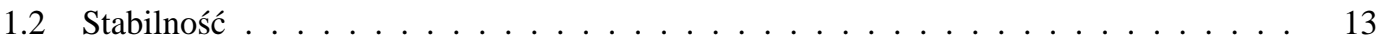

1.3 Baseny atrakcji rozwiązań . . . . . . . . . . . . . . . . . 14

1.4 Wartość parametru porządku rozwiązań . . . . . . . . . . . . . . 16

2 Przykładowe rozwiązania modelu lokalnego 19

$2.1 \quad N=3$, dowolny rozkład częstości f . . . . . . . . . . . . . . . . 19

$2.2 N=5$ : rozwiązania stabilne, parametr porządku, $k_{c}$, liczby nawinięć . . . . . . . 22

$2.3 N=6$ : kontrprzykład na pojawianie się jako pierwsze $m=0$, zachowanie parametru porządku i wartości własnych . . . . . . . . . . . . . . 26

$2.4 N$ dowolne: rozkłady zachowujące synchronizacje przy $N \rightarrow \infty \ldots \ldots 31$

3 Sprzężenie modyfikowane, asymetryczne $\quad 32$

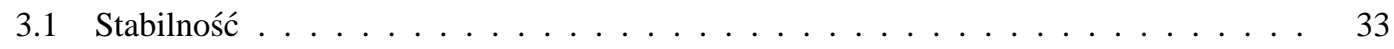

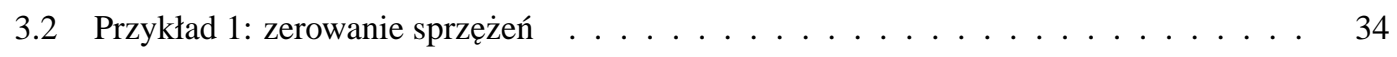

3.3 Przykład 2: wzajemne znoszenie się sprzężeń $\ldots \ldots \ldots$. . . . . . . . . . . 36

4 Sprzężenie modyfikowane, symetryczne $\quad 38$

4.1 Warunki istnienia rozwiązań zsynchronizowanych . . . . . . . . . . . . . 39

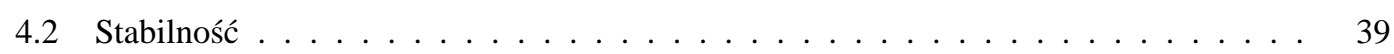

$\begin{array}{lr}\text { Podsumowanie } & \mathbf{4 0}\end{array}$ 
A Warunek rozwiązania układu liniowego

Bibliografia 


\section{Wstęp}

Niezliczona ilość procesów w przyrodzie ożywionej odbywa się cyklicznie, czego najoczywistszym dla człowieka przykładem może być rytm dobowy. W jaki jednak sposób w niezwykle skomplikowanych układach biologicznych - w wielokomórkowych narządach czy organizmach, a nawet w całych populacjach żywych istot - wyłaniać się może wspólny dla wszystkich ich częśsi składowych rytm, zaczynamy rozumieć dopiero od parudziesięciu lat. Wzrastające zainteresowanie czasem w procesach biologicznych doprowadziło już do wyodrębnienia się nowej dziedziny (a przynajmniej nowej nazwy), tzw. chronobiologii.

Kluczowym zagadnieniem jest tu właśnie zjawisko synchronizacji, czyli samoistnego dostrajania się układu wielu cyklicznie zachowujących się elementów do jednej, wspólnej częstości, pomimo pewnych różnic pomiędzy nimi. W przyrodzie takimi oscylatorami biologicznymi są między innymi komórki rozrusznikowe serca [1, 2] czy komórki rozrusznikowe mięśni jelit odpowiedzialne za perystaltykę [3]. Przykładami mogą być również procesy komórkowe, jak wydzielanie insuliny przez komórki trzustki [4] lub synchronizujące się procesy metaboliczne w zawiesinach komórek drożdży [5, 6].

Idąc dalej, mamy komórki odpowiedzialne za rytmy dobowe. Okazuje się, że organizmy żywe dostrajają się do cyklu światło-ciemność, ale pozostawione w ciemności niemal nie zmieniają cyklu dobowego. Świadczy to o tym, że rośliny (np. poruszająca liśćmi w górę i w dół zgodnie z cyklem światło-ciemność fasolka szparagowa) i zwierzęta (jak larwy muszki owocówki przeobrażające się w 24-godzinnym cyklu [7]) wytwarzają pewien wewnętrzny rytm. W bieżącym roku pokazano [8], że może istnieć kilka współzależnych, wewnętrznych zegarów biologicznych (opartych o sprzężone pętle transkrypcyjne) regulujących rytm dobowy.

Więcej nawet, zaobserwowano populacje organizmów, które potrafią się synchronizować bez żadnego zewnętrznego dostrajania. I tak, można ujrzeć drzewa pulsujące światłem jednocześnie migających świetlików południowo-wschodnio-azjatyckich $[9,10]$, usłyszeć cykające jednym głosem świerszcze północnoamerykańskie [11], a w końcu wpadające we wspólny rytm oklaski widowni [12, 13].

Synchronizacja nie jest jednak ograniczona do przyrody ożywionej. Występowanie tego zjawiska wykazano również w układach stworzonych przez człowieka - jeszcze w latach dwudziestych ubiegłego 
wieku zauważono je w połączonych generatorach triodowych. Obecnie próbuje się je stosować także w sieciach laserów półprzewodnikowych [14, 15] lub złączy Josephsona [16, 17].

\subsection{Model Kuramoto}

Pierwszy naukowy zapis dotyczący synchronizacji przypisuje się Christianowi Huygensowi, który w liście do ojca z 1665 opisał, jak dwa zegary z wahadłami, zawieszone na wspólnym stelażu, zawsze dostrajały się i tykały równocześnie, przy czym wahadła miały przeciwne wychylenia. Działo się tak nawet, gdy zaburzyło się ten układ, tzn. gdy ręcznie zmienione zostały wychylenia wahadeł. Huygens przypuszczał, że takie zachowanie spowodowane jest niezauważalnymi ruchami stelażu, które sprzęgają dwa zegary.

Na model opisujący synchronizację, który dałoby się badać metodami matematycznymi, trzeba było jednak długo czekać. Interesujące nas podejście zaproponował dopiero Winfree w 1967 roku [18]. Przyjął on, że jeśli oscylatory są prawie identyczne, a sprzężenie pomiędzy nimi jest słabe, to dokonuje się separacja skal czasowych - krótkoczasowa odpowiada relaksacji oscylatorów do ich stabilnych cykli granicznych (opisanych jedynie fazą), a długoczasowa odpowiada ewolucji faz wynikającej z oddziaływań pomiędzy oscylatorami (co można zapisać w postaci równań różniczkowych zwyczajnych pierwszego rzędu). Następnym krokiem było założenie o oddziaływaniu typu średniego pola, tzn. każdy oscylator miał być sprzężony ze wszystkimi pozostałymi, a więc miał odczuwać pewne średnie oddziaływanie z całym układem. Model ten wygląda zatem następująco:

$$
\dot{\theta_{i}}=\omega_{i}+\left(\sum_{j=1}^{N} X\left(\theta_{j}\right)\right) Z\left(\theta_{i}\right) \quad, i=1, \ldots, N \quad,
$$

gdzie fazy $\theta_{i} \in[0,2 \pi]$ parametryzują cykl graniczny (czyli pewną krzywą zamkniętą w przestrzeni fazowej), $\omega_{i}$ to częstości własne oscylatorów (czyli prędkość przejścia całego cyklu, gdy oscylator jest izolowany) wybrane według pewnego rozkładu $g(\omega)$, a funkcje $X\left(\theta_{j}\right)$ i $Z\left(\theta_{i}\right)$ to odpowiednio wkład do oddziaływania oscylatora $j$ i czułość na sprzężenie oscylatora $i$.

Jak wynikało z symulacji komputerowych Winfree'ego, takie układy mogą wykazywać synchronizację przy wystarczająco małym rozrzucie częstości własnych lub wystarczająco dużym sprzężeniu. Co więcej, gdy w danym układzie stopniowo zwiększa się sprzężenie, poniżej pewnej jego wartości układ jest zupełnie rozstrojony, podczas gdy powyżej tej wartości pewna makroskopowa grupa oscylatorów ustala wspólną częstość. Okazuje się więc, że mamy do czynienia z przejściem fazowym. Jednak największą wadą, jaką posiada model Winfree, jest to, że ciągle, mimo wielu uproszczeń, nie da się tych wniosków wyprowadzić analitycznie.

W 1975 roku do badań nad synchronizacją włączył się jednak Kuramoto. Pokazał on, że układ niemal identycznych oscylatorów na cyklach granicznych w skali długoczasowej zachowuje się zgodnie 
z równaniami

$$
\dot{\theta_{i}}=\omega_{i}+\sum_{j=1}^{N} \Gamma_{i j}\left(\theta_{j}-\theta_{i}\right), i=1, \ldots, N \quad .
$$

Dalej jest to problem zbyt skomplikowany, aby go ogólnie rozwiązać - z jednej strony nie ma określonej topologii sprzężeń układu, z drugiej funkcje sprzęgające $\Gamma_{i j}$ mogą mieć nieskończenie wiele składowych fourierowskich. Kuramoto przyjął zatem, że wszystkie funkcje sprzęgające mają postać sinusoidalną

$$
\Gamma_{i j}\left(\theta_{j}-\theta_{i}\right)=\frac{k}{N} \sin \left(\theta_{j}-\theta_{i}\right)
$$

gdzie $k \geq 0$ jest stałą sprzężenia, z czego wynika, że każdy oscylator jest sprzężony ze wszystkimi pozostałymi.

Dynamikę takiego układu, gdy rozkład częstości własnych jest jednomodalny i symetryczny, opisuje układ równań, gdzie fazy oscylatorów są sprzężone już jedynie ze średnim polem całego układu

$$
\dot{\theta}_{i}=\omega_{i}+k r \sin \left(\psi-\theta_{i}\right), i=1, \ldots, N
$$

gdzie parametry $r, \psi$ zdefiniowane są przez równanie

$$
r e^{i \psi}=\frac{1}{N} \sum_{j=1}^{N} e^{i \theta_{j}}
$$

Wielkość $r$ odgrywa jednocześnie rolę parametru porządku. Kuramoto pokazał analitycznie, że synchronizacja nieskończonego układu oscylatorów, tj. gdy $N \rightarrow \infty$, jest przejściem fazowym drugiego rodzaju. Powyżej pewnej krytycznej wartości stałej sprzężenia $k=k_{c}$ stan niespójny destabilizuje się i pojawia się makroskopowa populacja oscylatorów o jednakowej częstości - populacja zsynchronizowana. Analitycznie udało się wyznaczyć zarówno krytyczną stałą sprzężenia (w zależności od rozkładu częstotliwości), jak i zachowanie parametru porządku w pobliżu punktu krytycznego (wynik dokładny podano w szczególności dla rozkładu Cauchy’ego, jak również ogólnie dla rozkładów ze skończonymi ogonami)!

Do modelu Kuramoto szybko wprowadzono dodatkową modyfikację [19], po uwzględnieniu której równania opisujące układ przybierają postać

$$
\dot{\theta}_{i}(t)=\omega_{i}-\frac{k}{N} \sum_{j=1}^{N} \sin \left(\theta_{i}-\theta_{j}+\alpha\right) .
$$

Stała $\alpha \in[0, \pi / 2]$ to nowy parametr modelu - gdy się ona zeruje, wracamy do poprzednio rozważanego przypadku. W przeciwnym razie, wprowadza ona taką asymetrię sprzężenia, że oscylatory synchronizują się do częstości nie będącej średnią ich częstości własnych, jak dzieje się, gdy $\alpha=0$. Jest to dodatkowa zaleta modelu, gdyż w rzeczywistości również obserwuje się różnicę pomiędzy średnią częstości elementów układu, a częstością zsynchronizowaną. 
Warto w tym miejscu wskazać na artykuły wprowadzające w tematykę modelu Kuramoto, jak [20, 21], oraz obszerną pracę przeglądową dotyczącą dotychczasowych wyników prac nad modelem Kuramoto i jego modyfikacjami [22].

\subsection{Sprzężenie lokalne w modelu Kuramoto}

Model Kuramoto odniósł niewątpliwy sukces, przede wszystkim dzięki swojej prostocie. Korzystając z tego, warto wprowadzać pewne modyfikacje, które dałyby model bliższy rzeczywistości. Głównie próbuje się obecnie badać układy z lokalnymi oddziaływaniami pomiędzy oscylatorami, czemu ta praca jest poświęcona, czy też wprowadzać opóźnienia oddziaływań.

Najprostszym modelem lokalnym jest oczywiście sieć jednowymiarowa; w przypadku zadania periodycznych warunków brzegowych jest to po prostu okrąg. Taka topologia sieci określona jest naturalnie przez oddziaływania, które w łańcuchu $N$ kolejnych oscylatorów sprzęgają dany element wyłącznie z jednym bezpośrednio poprzedzającym go oraz jednym następującym po nim elementem. Najogólniejsze z dotychczasowych wyników dla skończeniewymiarowego modelu Kuramoto mówią w szczególności, że w granicy termodynamicznej $(N \rightarrow \infty)$, w jednym wymiarze nie wykazuje on długozasięgowego porządku (tj. synchronizacji), co zostało potwierdzone ścisłym dowodem przez Strogatza [23] (zakładając rozkład normalny częstości własnych oscylatorów), a było sugerowane wcześniej przez Sakaguchiego i in. [24]. Podobną analizę przeprowadził Daido [25] dla rozkładów częstości własnych z ogonami potęgowymi typu $g(\omega) \sim \omega^{-\gamma-1},|\omega| \gg 1$. Wynika z niej, że gdy $0<\gamma \leq 1$, to synchronizacja częstotliwościowa $\mathrm{w}$ granicy termodynamicznej nie występuje w żadnym skończeniewymiarowym układzie, natomiast gdy $1<\gamma \leq 2$ (graniczna wartość $\gamma=2$ odpowiada rozkładom o skończonej wariancji, czyli np. rozkładowi Gaussa), to synchronizacja może występować jedynie powyżej wymiaru $d=\gamma /(\gamma-1)$.

Wydaje się, że jest to zachowanie analogiczne do modelu Isinga, gdzie również nie zachodzi przejście fazowe w jednym wymiarze (skrót dotyczący rozwiązania modelu Isinga na pierścieniu oraz dodatkowy komentarz, dlaczego nie może tam wystąpić przejście fazowe można znaleźć m.in. w [26]). W modelu Isinga jednakże, przejścia nie ma ani w nieskończonym, ani skończonym układzie, podczas gdy jednowymiarowy model Kuramoto wykazuje synchronizację dla skończonej liczby oscylatorów (dowód Strogatza wskazywał na potrzebę skalowania się krytycznej stałej sprzężenia, jak $N^{1 / 2}$, a więc rosła by ona do nieskończoności w nieskończonym układzie). 


\subsection{Układ pracy}

Przedstawione w niniejszej pracy zagadnienia dotyczą przede wszystkim znajdywania rozwiązań zsynchronizowanych na pierścieniu sprzężonych oscylatorów, ich liczby, stabilności i konkurencji pomiędzy nimi. Dodatkowo rozważam, z jakim rodzajem synchronizacji mamy tu do czynienia - fazowej czy jedynie częstotliwościowej. Wyniki te wyprowadzam w pełnej ogólności w rozdziale 1.

Kolejne podrozdziały w rozdz.2 mają na celu wyjaśnienie poszczególnych zagadnień poprzez rozwiązanie prostych, w pełni określonych układów, i zobrazowanie ich wynikami numerycznymi. W podrozdziale 2.4 wskazuję dodatkowo na pewne synchronizujące się układy nieskończone.

Rozdziały 3 i 4 poświęcone są analizie modelu z dodatkowo zmodyfikowanym sprzężeniem, jak wspomniałem we wprowadzeniu do modelu Kuramoto, w dziale 0.1. Standardowa zmiana członu sprzęgającego na asymetryczny $\sin \left(\theta_{i}-\theta_{i \pm 1}+\alpha\right)$ jest badana w rozdz.3, natomiast modyfikacja wprowadzona w rozdz.4 rozróżnia sprzężenie z sąsiadem ,z przodu” i ,z tyłu” zmieniając odpowiednio znak parametru $\pm \alpha$.

Pomimo, że ogólne wyniki wyprowadzone są dla układu o dowolnym rozmiarze $N$ i rozkładzie częstości własnych, oczywiście podlegają one ograniczeniom przywołanego powyżej, w podrozdz. 0.2, twierdzenia dla układu jednowymiarowego. Co prawda wskazuję na pewne synchronizujące się układy nieskończone, lecz, skoro w przyrodzie mamy do czynienia z układami ograniczonymi, i tutaj jako dominującą przyjmuję perspektywę układów skończonych. 


\section{Rozdział 1}

\section{Lokalny, jednowymiarowy model}

\section{Kuramoto}

Rozważmy 1-wymiarowy układ $N$ oscylatorów sprzężonych z ich najbliższymi sąsiadami, z periodycznymi warunkami brzegowymi. Sprzężenie ma standardową postać podaną przez Kuramoto:

$$
\dot{\theta}_{i}(t)=\omega_{i}-\frac{k}{2}\left[\sin \left(\theta_{i}(t)-\theta_{i-1}(t)\right)+\sin \left(\theta_{i}(t)-\theta_{i+1}(t)\right)\right],
$$

gdzie $i=1,2, \ldots, N$ oraz $\theta_{0} \equiv \theta_{N}, \theta_{N+1} \equiv \theta_{1}$.

Interesuje nas zagadnienie, kiedy oscylatory mogą się zsynchronizować, tj. kiedy

$$
\theta_{i}(t)=\Omega t+\phi_{i}
$$

Jeśli $\Omega$ jest równa zero, równanie (1.2) zadaje punkt stacjonarny układu. Podstawiwszy równanie (1.2) do (1.1) otrzymuje się układ równań:

$$
\omega_{i}-\frac{k}{2}\left(\sin \left(\phi_{i}-\phi_{i-1}\right)+\sin \left(\phi_{i}-\phi_{i+1}\right)\right)=\Omega
$$

przy $i=1,2, \ldots, N$. Zauważmy, że $\Omega$ musi być stałą, niezależną od czasu, ponieważ lewa strona powyższego równania jest również stałą. Ponieważ wszystkie oscylatory mają jednakową częstotliwość i różnią się jedynie fazami $\phi_{i}$, to przez rozwiązanie układu (1.3) będziemy rozumieć układ stałych różnic fazowych $\phi_{i}-\phi_{i-1}$, które wytwarzają się pomiędzy kolejnymi oscylatorami. W wyniku antysymetrii funkcji sinus oraz założenia o periodycznych warunkach brzegowych zsumowanie równań (1.3) prowadzi do

$$
\Omega=\frac{1}{N} \sum_{i=1}^{N} \omega_{i}
$$


tj. zsynchronizowana częstość równa się średniej częstości poszczególnych oscylatorów. Należy zauważyć, że dla każdego układu skończonego średnia istnieje. Jednakże w granicy $N \rightarrow \infty$ średnia częstość istnieje tylko, jeśli rozkład odpowiadający częstościom własnym ma pierwszy moment. W dalszej części przedstawimy dalsze ograniczenia na rozkłady częstości normalnych oscylatorów.

Układ równań (1.3) przyjmuje postać macierzową

$$
A s=\frac{2}{k}(\omega-\Omega e)
$$

gdzie $e=[1,1, \ldots, 1]^{T}, s=\left[\sin \left(\phi_{1}-\phi_{N}\right), \sin \left(\phi_{2}-\phi_{1}\right), \ldots, \sin \left(\phi_{N}-\phi_{N-1}\right)\right], \omega=\left[\omega_{1}, \omega_{2}, \ldots, \omega_{N}\right]^{T}$, oraz

$$
A=\left[\begin{array}{rrrrr}
1 & -1 & & & \\
& 1 & -1 & & \\
& & \ddots & \ddots & \\
& & & 1 & -1 \\
-1 & & & & 1
\end{array}\right] .
$$

Ponieważ każdy $\left|s_{i}\right| \leq 1$, to (1.5) nie może zostać rozwiązane dla

$$
\left|\omega_{i}-\Omega\right|>k
$$

Jednocześnie, dla dowolnych $\omega_{i}$ takich, że

$$
\left|\omega_{i}-\Omega\right| \leq k
$$

równanie (1.5) w ogólności nie musi mieć rozwiązania.

Możemy już stwierdzić, że zsynchronizowany ruch nie istnieje, jeśli którakolwiek wartości $\omega_{i}$ różni się od średniej o więcej niż $k$. Jedynie system jednorodny może synchronizować się dla dowolnej wartości $k$, natomiast jeśli $k \rightarrow \infty$, to każdy układ może się zsynchronizować. Dla każdego układu istnieje zatem krytyczna wartość parametru sprzężenia $k_{c}$, szacowana od dołu przez

$$
k_{c} \geq \max _{i}\left|\omega_{i}-\frac{1}{N} \sum_{j=1}^{N} \omega_{j}\right| \quad,
$$

taka, że układ (1.1) może się w pełni synchronizować dla $k>k_{c}$ i nie może dla $k<k_{c}$.

Wynika stąd, że rozkład częstości własnych układu nieskończonego, $N \rightarrow \infty$, musi mieć ucięte „ogony”, aby istniało jakiekolwiek rozwiązanie zsynchronizowane. Poniżej, w rozdz.1.1 pojawią się kolejne ograniczenia na rozkład częstości własnych oraz zostanie podany przepis na znajdywanie $k_{c}$ dla układów mogących synchronizować się. 


\subsection{Znajdywanie rozwiązań zsynchronizowanych}

Oznaczmy odchylenia od średniej zsynchronizowanej częstości przez $\Delta_{i} \equiv\left(\omega_{i}-\Omega\right)$, wtedy układ (1.5) przyjmuje postać

$$
\left[\begin{array}{rrrrr}
1 & -1 & & & \\
& 1 & -1 & & \\
& & \ddots & \ddots & \\
& & & 1 & -1 \\
-1 & & & & 1
\end{array}\right]\left[\begin{array}{c}
s_{1} \\
s_{2} \\
\vdots \\
s_{N-1} \\
s_{N}
\end{array}\right]=\frac{2}{k}\left[\begin{array}{l}
\Delta_{1} \\
\Delta_{2} \\
\vdots \\
\Delta_{N-1} \\
\Delta_{N}
\end{array}\right]
$$

Jeśli ma on mieć rozwiązanie, musi zachodzić $\operatorname{rank}(A \mid B)=\operatorname{rank}(A)=N-1$, gdzie $B$ jest wyrazem wolnym. Żeby rząd macierzy dołączonej był równy $N-1$, wystarczy sprawdzić, czy jest różny od $N$. Do tego wystarczy, by wyznaczniki macierzy stworzonych z dowolnych $N-1$ kolumn macierzy $A$ i wyrazu wolnego przyrównać do zera. Ścisłe rachunki podaję w Dodatku A. Wynika stąd warunek rozwiązywalności układu liniowego (1.10) ze względu na wielkości $s_{i} \in \mathbb{R}$ :

$$
\sum_{i=1}^{N} \Delta_{i}=0
$$

powtarzający warunek na średnią częstość $\Omega$ (1.4).

Ogólne rozwiązanie równania (1.5) będzie zależało od jednego parametru rzeczywistego, ponieważ rząd macierzy $A=N-1<N$. Przyjmując $s_{N}=p$, tj. jako parametr rozwiązania, mamy układ zapisany inaczej, jako

$$
\begin{aligned}
& s_{N}=p \\
& s_{N-1}=\frac{2}{k} \Delta_{N-1}+p \\
& s_{N-2}=s_{N-1}+\frac{2}{k} \Delta_{N-2}+p=\frac{2}{k} \Delta_{N-1}+\frac{2}{k} \Delta_{N-2}+p \\
& \vdots \\
& s_{1}=\frac{2}{k} \sum_{i=1}^{N-1} \Delta_{i}+p,
\end{aligned}
$$

przy czym $\Delta_{i}$ są związane warunkiem $\sum_{i=1}^{N} \Delta_{i}=0$.

Należy teraz przypomnieć, że $s_{i} \equiv \sin \left(\phi_{i}-\phi_{i-1}\right)$, a więc $\left|s_{i}\right| \leq 1$. Nałożenie tego warunku na wszystkie składowe rozwiązania (1.12) daje nietrywialne ograniczenie na dobór rozwiązania (zakres wartości parametru $p$ ) w zależności od rozkładu częstości $\omega_{i}$. Zauważmy, że jest to warunek różny od podanego w (1.8).

Jeśli uwzględni się równanie $\sum_{i=1}^{N} \Delta_{i}=0$, to układ warunków przyjmuje postać 


$$
\begin{aligned}
|p| & \leq 1 & \Leftrightarrow & \left|p+\frac{2}{k} \sum_{i=1}^{N} \Delta_{i}\right| \leq 1 \\
\left|p+\frac{2}{k} \Delta_{N-1}\right| \leq 1 & \Leftrightarrow & & \left|p-\frac{2}{k} \sum_{i=1}^{N-2} \Delta_{i}-\frac{2}{k} \Delta_{N}\right| \leq 1 \\
\left|p+\frac{2}{k} \Delta_{N-1}+\frac{2}{k} \Delta_{N-2}\right| \leq 1 & \Leftrightarrow & & \left|p-\frac{2}{k} \sum_{i=1}^{N-3} \Delta_{i}-\frac{2}{k} \Delta_{N}\right| \leq 1 \\
\left|p+\frac{2}{k} \sum_{i=1}^{N-1} \Delta_{i}\right| \leq 1 & & \Leftrightarrow & \left|p-\frac{2}{k} \Delta_{N}\right| \leq 1,
\end{aligned}
$$

Widać, że dla danego zestawu $\omega_{i}, i=1, \ldots, N$, zmiana parametru sprzężenia $k$ na odpowiednio duży powoduje spełnienie wszystkich tych warunków i pojawienie się zsynchronizowanego rozwiązania.

Równania (1.12) można odwikłać ze względu na różnicę faz na dwa sposoby, przykładowo:

$$
\phi_{N}-\phi_{N-1}=\left\{\begin{array}{ll}
\arcsin (p)+2 n_{N} \pi & \in\left(-\pi / 2+2 n_{N} \pi, \pi / 2+2 n_{N} \pi\right] \\
-\arcsin (p)+\pi+2 n_{N}^{\prime} \pi & \in\left(\pi / 2+2 n_{N}^{\prime} \pi, 3 \pi / 2+2 n_{N}^{\prime} \pi\right]
\end{array},\right.
$$

gdzie $n_{N}, n_{N}^{\prime} \in \mathbb{Z}$. Bez straty ogólności możemy położyć $n_{i}=n_{i}^{\prime}=0$, gdyż układ jest określony tylko przez funkcje o okresie $2 \pi$. Wybierając dla którejkolwiek różnicy faz drugi z powyższych sposobów, otrzymamy rozwiązania, które moga być niestabilne (szczegółowe wyjaśnienie kwestii stabilności znajduje się w rozdz.1.2). Zapisując wszystkie różnice faz według pierwszego sposobu, dostajemy układ dla rozwiązań stabilnych postaci

$$
\begin{aligned}
\phi_{N}-\phi_{N-1} & =\arcsin p \\
\phi_{N-1}-\phi_{N-2} & =\arcsin \left(p+\frac{2}{k} \Delta_{N-1}\right) \\
\phi_{N-2}-\phi_{N-3} & =\arcsin \left(p+\frac{2}{k} \Delta_{N-1}+\frac{2}{k} \Delta_{N-2}\right) \\
\vdots & \\
\phi_{1}-\phi_{N} & =\arcsin \left(p+\frac{2}{k} \sum_{i=1}^{N-1} \Delta_{i}\right) .
\end{aligned}
$$

Z powodu założenia o periodycznych warunkach brzegowych, po zsumowaniu stronami, otrzymuje się dodatkową rodzinę alternatywnych warunków wiążących parametr rozwiązania $p$ oraz składowe rozkładu częstości:

$$
\sum_{i=0}^{N-1} \arcsin \left(p+\frac{2}{k} \sum_{j=1}^{i} \Delta_{j}\right)=2 m \pi
$$

Rzecz jasna, suma lewych stron (1.15), traktowana czysto symbolicznie, daje 0. Można sobie jednak wyobrazić sytuację, gdy wszystkie kolejne różnice faz są dodatnie i po kolei zsumowane dochodzą 
do $2 \pi$ lub wielokrotności tej liczby (patrz rys.2.5). Mówimy wtedy o kolejnych „nawinięciach”, które ostatnie, zszywające równanie na $\phi_{1}-\phi_{N}$ musi zliczać. Stąd prawa strona (1.16) uwzględnia ilość owych nawinięć.

Aby wyznaczyć możliwe rozwiązania, korzystając z (1.16), musimy sprawdzić $m$ równań. W ogólności każde z nich może zawierać poprawne rozwiązanie - wyznaczany z nich jest inny parametr $p$ i stąd inne różnice fazowe. Przyjmujemy, że spełnione są warunki (1.13), a więc wszystkie arcus sinusy są dobrze zdefiniowane. Każde z $m$ równań ma wtedy co najwyżej jeden pierwiastek, ponieważ po lewej stronie (1.16) stoi suma ściśle rosnących funkcji określonych na tym samym przedziale, a więc ta suma też jest funkcją różnowartościową ściśle rosnącą. Ilość nawinięć maksymalnie przebiega zakres

$$
m=-\lfloor N / 4\rfloor,-\lfloor N / 4\rfloor+1, \ldots,-1,0,1, \ldots,\lfloor N / 4\rfloor,
$$

gdzie $\lfloor$.$\rfloor oznacza ,podłogę", tj. największą liczbę całkowitą mniejszą lub równą od danej liczby$ (np. $\lfloor 3.2\rfloor=3$, ale $\lfloor 3\rfloor=3$ ). Łatwo ustalić ten zakres, biorąc $k \rightarrow \infty$, ponieważ wtedy wszystkie arcus sinusy mają postać $\arcsin (p)$ i moga przyjmować pełen zakres wartości dla $p \in[-1,1]$. Oznacza to, że maksymalnie, czyli dla $k \rightarrow \infty$ lub układu identycznych oscylatorów, można uzyskać $1+2 \cdot\lfloor N / 4\rfloor$ różnych stabilnych rozwiązań. Zaznaczmy, że to, do którego stabilnego rozwiązania zsynchronizowanego układ dojdzie, zależy od warunków początkowych (tzn. od początkowego rozkładu faz oscylatorów).

Ten problem szczegółowo podejmuje rozdz.1.3.

Oczywiście, gdy w (1.14) nie zawsze będziemy wybierać pierwszy sposób odwikłania, otrzymamy inne równania. W sumie będzie ich $2^{N-1}$, bo mamy dwie możliwości odwikłania i $N-1$ niezależnych różnic fazowych. Lewa strona tych równań może być nieróżnowartościowa, oraz zakres możliwej liczby nawinięć $m$ może być dla nich inny. Przekłada się to również na inną liczbę ich rozwiązań. Odpowiadają one rozwiązaniom, o których nie jesteśmy w stanie powiedzieć, że są stabilne, lub są na pewno niestabilne. Zagadnienie to zostanie zilustrowane w rozdz.2.2.

Pośrednio z równania (1.16) lub wprost z warunków (1.13) wynika też inny bardzo ważny wniosek. Ponieważ parametr rozwiązania $p \in[-1,1]$, więc gdy istnieje taka suma odchyleń częstości, że $\left|\frac{2}{k} \sum_{j=1}^{i} \Delta_{j}\right|>1$, rozwiązanie zsynchronizowane nie będzie istnieć. Oznacza to, że jeśli dla układu o $N \rightarrow \infty$ maksimum takich sum rośnie, jak $N$ w pewnej potędze, to również stała sprzężenia musi rosnąć do nieskończoności w tej samej potędze, żeby cały układ mógł się zsynchronizować. Pokazał to wcześniej Strogatz [23], korzystając z analogii pomiędzy kolejnymi losowymi odchyleniami $\Delta_{i}$ częstości oscylatorów od średniej, a krokami jednowymiarowego błądzenia przypadkowego. Gdy niezależnie każdemu oscylatorowi przydzielona jest z równym prawdopodobieństwem częstość $+\omega$ lub $-\omega$, zachodzi w przybliżeniu $\max _{1 \leq i \leq N}\left|\sum_{j=1}^{i} \Delta_{j}\right| \sim N^{1 / 2}$. Wynik ten stosuje się jednak do dowolnego rozkładu niezależnie rozlosowanych na okręgu częstości własnych. 
Oczywiście ciągle synchronizować się może każdy układ skończony, a nadto można konstruować rozkłady częstotliwości, dla których możliwa jest również synchronizacja dla $N \rightarrow \infty$ (patrz rozdz.2.3).

Zauważmy, że definicja $k_{c}$ dla modelu średniopolowego Kuramoto subtelnie różni się od przyjętej tutaj. Przy globalnym sprzężeniu $k_{c}$ oznaczała taką wartość parametru $k$, że parametr porządku $r=0$ dla $k<k_{c}$ oraz $r>0$ dla $k>k_{c}$. Innymi słowy, powyżej $k_{c}$ pojawiała się pewna makroskopowa zsynchronizowana populacja oscylatorów; obok niej istniała jednak pewna populacja zdesynchronizowana. Podane tutaj wyniki odpowiadają sytuacji, gdy synchronizuje się cały układ.

Możliwe jest podanie procedury otrzymywania stałej $k_{c}$ dla dowolnego $N$ oraz rozkładu częstości. Należy wyznaczyć

$$
\begin{aligned}
& \min \equiv \min _{i=0, \ldots, N-1}\left(\sum_{j=1}^{i} \Delta_{j}\right) \\
& \max \equiv \max _{i=0, \ldots, N-1}\left(\sum_{j=1}^{i} \Delta_{j}\right),
\end{aligned}
$$

następnie obliczyć zakres wartości lewej strony równania (1.16)

$$
L \in\left[\sum_{i=0}^{N-1} \arcsin \left(\frac{2}{k} \sum_{j=1}^{i} \Delta_{j}-\frac{2}{k} \min -1\right), \sum_{i=0}^{N-1} \arcsin \left(\frac{2}{k} \sum_{j=1}^{i} \Delta_{j}-\frac{2}{k} \max +1\right)\right]
$$

oraz znaleźć wartości $k$, dla których krańce tego przedziału są równe $2 m \pi$, i wybrać najmniejszą z nich. Problemem jest brak zwięzłego ,wzoru na $k_{c}$ ”, zamiast którego mamy jedynie algorytm jej wyznaczania. Konkretny przykład wyznaczania $k_{c}$ można znaleźć na początku rozdziału 1.6.

\subsection{Stabilność}

Przyjmijmy, że $\left\{\theta_{i}(t)\right\}_{i=1}^{N}=\left\{\Omega t+\phi_{i}\right\}_{i=1}^{N}$ jest rozwiązaniem zsynchronizowanym układu (1.1). Aby zbadać jego stabilność, zaburzamy to rozwiązanie: $\forall i: \theta_{i}(t) \rightarrow \theta_{i}(t)+u_{i}(t)$, gdzie $\left|u_{i}(t)\right| \ll 1$ i podstawiamy do (1.1). Po rozwinięciu prawej strony równania do pierwszego rzędu ze względu na $u_{i}$ otrzymujemy:

$$
\dot{u} \simeq-\frac{k}{2}\left[\begin{array}{ccccc}
c_{1}+c_{2} & -c_{2} & & & -c_{1} \\
-c_{2} & c_{2}+c_{3} & -c_{3} & & \\
& -c_{3} & c_{3}+c_{4} & -c_{4} & \\
& \ddots & \ddots & \ddots & \\
& & -c_{N-1} & c_{N-1}+c_{N} & -c_{N} \\
-c_{1} & & & -c_{N} & c_{N}+c_{1}
\end{array}\right] u
$$


gdzie $u=\left[u_{1}(t), u_{2}(t), \ldots, u_{N}(t)\right]^{T}, c_{i}=\cos \left(\phi_{i}-\phi_{i-1}\right)$.

Przyjmujemy w tych rozważaniach, że różnice faz $\phi_{i}-\phi_{i-1} \in[-\pi, \pi](\bmod 2 \pi)$. Ze względu na swoją cykliczną strukturę, macierz w (1.18) zawsze posiada zerową wartość własną, więc dowolne rozwiązanie (1.1) jest neutralnie stabilne ze względu na jednorodne przesunięcia (,sztywny obrót" układu) $\forall i: \phi_{i} \rightarrow \phi_{i}+\tilde{\phi}$. Znaki pozostałych wartości własnych zależą od wartości $c_{i}$.

Korzystamy z tw. Gerszgorina (obszerniejsze jego sformułowanie, dowód i zastosowanie można znaleźć m.in. w klasycznej literaturze dotyczącej zer wielomianów [27] lub analizy numerycznej [28]): dla macierzy $\left[a_{i j}\right]_{i, j=1, \ldots, N}$ każda jej wartość własna znajduje się w pewnym kole (tzw. dysku Gerszgorina) danym przez $\left\{z:\left|z-a_{i i}\right| \leq R_{i}\right\}$, gdzie $R_{i}=\sum_{j=1 j \neq i}^{N}\left|a_{i j}\right|, i=1, \ldots, N$.

W macierzy zadanej przez (1.18) $a_{i i} \in R$. Twierdzenie to klasyfikuje rozwiązania na 3 przypadki:

(i) $\forall i: c_{i}>0$ (czyli $\left.\forall i:\left|\phi_{i}-\phi_{i-1}\right|<\pi / 2\right) \Rightarrow$ rozwiązania są stabilne (ew. neutralnie stabilne: wszystkie dyski Gerszgorina leżą w lewej półpłaszczyźnie zespolonej i zawierają punkt $(0,0)$, więc wszystkie wartości własne $\lambda_{i}$ mają $\operatorname{Re} \lambda_{i} \leq 0$ )

(ii) $\forall i: c_{i}<0\left(\right.$ czyli $\left.\forall i:\left|\phi_{i}-\phi_{i-1}\right|>\pi / 2 \quad(\bmod 2 \pi)\right) \Rightarrow$ rozwiązania są niestabilne (wszystkie dyski Gerszgorina leżą w prawej półpłaszczyźnie zespolonej, więc wszystkie wartości własne $\lambda_{i}$ mają $\left.\operatorname{Re} \lambda_{i} \geq 0\right)$

(iii) $\exists i: c_{i}>0 \wedge \exists j: c_{j}<0 \Rightarrow$ nie możemy wnioskować o stabilności rozwiązań

Dodatkowego wyjaśnienia może wymagać podpunkt (iii). Opisuje on sytuację, gdy przynajmniej jeden dysk Gerszgorina leży częściowo w prawej, a częściowo w lewej półpłaszczyźnie zespolonej. Ponieważ jednak twierdzenie mówi o sumie mnogościowej wszystkich dysków, to nie można osądzić, ani czy w ogóle jakakolwiek wartość własna jest w tym konkretnym, „niepewnym” dysku zlokalizowana, ani w której jego części (dodatniej czy ujemnej) miałaby się ona znajdować. Mogą zatem istnieć rozwiązania leżące poza warunkiem $(i)$, ale które są stabilne, oraz rozwiązania leżące poza warunkiem (ii), a które są niestabilne. Dodatkowo, widać, że dla szczególnego przypadku $\forall i: c_{i}=0$ (czyli $\forall i:\left|\phi_{i}-\phi_{i-1}\right|=\pi / 2$ ) rozwiązanie jest neutralnie stabilne (wszystkie wartości własne są równe 0).

\subsection{Baseny atrakcji rozwiązań}

Spodziewamy się, że mając kilka możliwych rozwiązań zsynchronizowanych, odpowiadających różnej liczbie nawinięć $m$, układ będzie „wybierał” któreś z nich w zależności od zadanych warunków początkowych (tj. początkowego ustawienia faz oscylatorów, ponieważ mamy układ równań różniczkowych pierwszego rzędu). Przykład opisany w rozdz.2.2 sugeruje coś więcej: wielkość basenu atrakcji 
zależy od $m$ i spodziewamy się, że istnieje pewne rozwiązanie dominujące o małym $m$, które w granicy dużych $N$ będzie przyciągało makroskopową ilość lub nawet większość warunków początkowych. Pozostałe rozwiązania miałyby mieć baseny atrakcji malejące wraz ze wzrostem liczby nawinięć oraz zanikające w granicy dużych $N$.

Wydaje się, że baseny atrakcji stanowią spójne (topologicznie) obszary zawierające dane rozwiązanie stabilne. Gdyby tak nie było, układ, dochodząc do danego rozwiązania, musiałby przechodzić przez basen atrakcji innego rozwiązania. Ponieważ każdy punkt trajektorii układu jest tożsamy pewnemu warunkowi początkowemu, oznacza to sprzeczność, bo wychodząca z niego trajektoria musi dochodzić do innego atraktora.

Przypuszczamy, że wielkość basenu atrakcji jest powiązana z największą ujemną wartością własną macierzy zaburzenia danego rozwiązania (należy pamiętać, że rozważamy rozwiązania stabilne, a więc takie, których wartości własne są ujemne). Znaczyć by to miało, że „mało stabilne” rozwiązania, tzn. o maksymalnej wartości własnej bliższej zeru, będą miały mniejszy basen atrakcji niż rozwiązania „bardziej stabilne” - o największej wartości własnej dalszej od zera. Wynika to stąd, że zadanie warunków początkowych różnych od danego rozwiązania stabilnego jest zasadniczo zaburzeniem rozwiązania. A więc dojście układu do stanu zsynchronizowanego od pewnych bliskich mu warunków początkowych, to inaczej powrót układu do danego rozwiązania po zaburzeniu go. Ponieważ różne ujemne wartości własne określają szybkość takiego powrotu dla różnych zaburzeń, więc także mówią, z których warunków początkowych można dojść do którego rozwiązania. Argument ten oczywiście staje się jedynie hipotezą, gdy warunki początkowe znacznie odbiegają od rozwiązania - pamiętać należy, że w analizie stabilności przyjmujemy wielkość perturbacji $\left|u_{i}(t)\right| \ll 1$.

Przeprowadźmy bardzo uproszczone rozumowanie: załóżmy, że dla rozwiązania o danym $m$ wszystkie różnice fazowe wynoszą $\delta_{m}$. Liniowe zaburzenie spełnia wtedy równanie

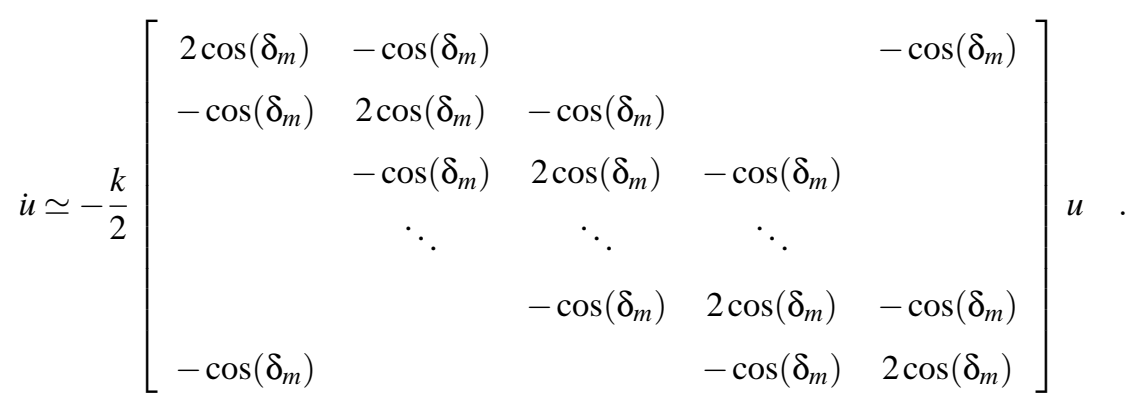

Macierz zaburzenia jest więc proporcjonalna do $\cos \left(\boldsymbol{\delta}_{m}\right)$, a znaczy to tyle, że jej wszystkie wartości własne spełniają $\lambda_{i}=-a_{i} k \cos \left(\delta_{m}\right)$, gdzie $a_{i}$ to pewne dodatnie współczynniki. Wedle poczynionego założenia $\delta_{m}=\frac{2 \pi}{N} m<\frac{\pi}{2}$, a więc

$$
\lambda_{i}=-a_{i} k \cos \left(\frac{2 \pi}{N} m\right) \in\left[-a_{i} k, 0\right] .
$$


Wynika stąd, że w tym idealnym wypadku najbardziej stabilne są rozwiązania o najmniejszej liczbie nawinięć i to one mają największy basen atrakcji. Dla każdego kolejnego rozwiązania o wyższym $m$ baseny atrakcji maleją.

W rzeczywistości różnice fazowe mogą się znacznie różnić, a wartości własne stają się wtedy nieliniowymi kombinacjami różnych cosinusów i trudno przewidzieć ich wielkość. Na podstawie tw. Gerszgorina można wprowadzić dolne oszacowanie na maksymalną wartość własną, zależy ono jednak od $\max _{i}\left(\left|\cos \left(\delta_{i}\right)\right|+\left|\cos \left(\delta_{i+1}\right)\right|\right)$. Dokładność oszacowania może więc zniweczyć jedna mała różnica faz $\delta_{i}$, i w ogólności jest ono coraz gorsze dla coraz mniejszych $\delta_{i}$.

Należy jednak zauważyć, że dla $m$ stosunkowo dużego, tj. niewiele mniejszego od $\lfloor N / 4\rfloor$, dane rozwiązanie może kompensować pewną dużą różnicę fazową inną, małą, tylko w ograniczonym stopniu, ponieważ z jednej strony musi się zdołać nawinąc na okrąg $m$ razy, a z drugiej żądamy, aby żadna różnica faz nie przekraczała $\pi / 2$. Różnice faz muszą się więc „rozciągnąć” do ok. $\pi / 2$ i wartości własne rzeczywiście bliższe będą zeru. Rozwiązania o małym $m$ nie są ograniczone z takich powodów.

Trudno obecnie wnioskować o ciaggłości przejścia „zerowy - skończony basen atrakcji”, wpływ na podane wyniki mogą mieć m.in. dokładność numeryczna.

\subsection{Wartość parametru porządku rozwiązań}

Stopień synchronizacji w modelu Kuramoto mierzy się za pomocą parametru porządku $r$ :

$$
r(t) \cdot e^{i \psi(t)}=\frac{1}{N} \sum_{j=1}^{N} e^{i \theta_{j}(t)}
$$

Parametr $r(t)$ wskazuje na to, czy fazy oscylatorów są rozłożone równomiernie „na okręgu” (przyjmujemy przedział $(-\pi, \pi])$, co miałoby oznaczać przypadkowość i brak synchronizacji $(r \approx 0)$ lub są skupione w danym miejscu (synchronizacja, $r \approx 1$ ). Trzeba jednakże rozróżnić pomiędzy synchronizacją, gdzie następuje koherencja faz (,phase coherence”, kiedy rzeczywiście $r \approx 1$ ), a rozwiązaniami „frequency-locked” (tzn. gdzie jedyny warunek to $\dot{\theta_{i}}=$ const $=\Omega$, często określa się je również jako „phase-locked”) oraz tymi, gdzie jednakowa jest jedynie uśredniona po czasie częstość.

Dla modelu (1.1) w stanie zsynchronizowanym $\theta_{i}(t)=\Omega t+\phi_{i}$ :

$$
r(t)=\frac{1}{N}\left|\sum_{j=1}^{N} e^{i \phi_{j}}\right|
$$


Oznaczmy różnice faz $\delta_{j} \equiv \phi_{j}-\phi_{j-1}$. Rozważamy funkcję

$$
\begin{aligned}
& F_{N}\left(\delta_{1}, \delta_{2}, \ldots, \delta_{N-1}\right)=\left|\sum_{j=1}^{N} e^{i \phi_{j}}\right|^{2} \\
& =\left[1+e^{-i \delta_{1}}+e^{-i\left(\delta_{1}+\delta_{2}\right)+\ldots+e^{-i\left(\delta_{1}+\delta_{2}+\ldots+\delta_{N-1}\right)}}\right] \cdot\left[1+e^{i \delta_{1}}+e^{i\left(\delta_{1}+\delta_{2}\right)+\ldots+e^{i\left(\delta_{1}+\delta_{2}+\ldots+\delta_{N-1}\right)}}\right] \\
& =N+2 \sum_{j=1}^{N-1} \cos \delta_{j}+2 \sum_{j=1}^{N-2} \cos \left(\delta_{j}+\delta_{j+1}\right)+\ldots+ \\
& +2 \sum_{j=1}^{2} \cos \left(\boldsymbol{\delta}_{j}+\delta_{j+1}+\ldots+\delta_{j+N-3}\right)+2 \cos \left(\delta_{1}+\delta_{2}+\ldots+\delta_{N-1}\right)
\end{aligned}
$$

Zauważmy, że przez periodyczne warunki brzegowe $r=\left(\sqrt{F_{N}} / N\right)$ zależy od $N-1$ różnic fazowych.

Możliwe jest sprawdzenie wartości parametru porządku w przypadkach o szczególnie wybranych różnic faz. Przy dowolnym rozmiarze układu $N$ wyliczam parametr porządku $r$ oraz rozkład częstości własnych oscylatorów, dla których dane ustawienie jest możliwe (jest rozwiązaniem). Rozpatruję przypadki, kiedy fazy oscylatorów rozwiązania zsynchronizowanego są:

- równe sobie

- odległe jedna od kolejnej o $\pi / 2$ (przypadek neutralnie stabilny)

- odległe jedna od kolejnej naprzemian o $+\delta \mathrm{i}-\delta$, gdzie $\delta \in[0, \pi / 2]$

Łatwo wykazać, że zachodzi związek rekurencyjny:

$$
\begin{aligned}
F_{k+1}\left(\delta_{1}, \delta_{2}, \ldots, \delta_{k-1}, \delta_{k}\right) & =F_{k}\left(\delta_{1}, \delta_{2}, \ldots, \delta_{k-1}\right)+ \\
& +1+2 \cos \delta_{k}+2 \cos \left(\delta_{k-1}+\delta_{k}\right)+\ldots+2 \cos \left(\delta_{1}+\delta_{2}+\ldots+\delta_{k}\right)
\end{aligned}
$$

Widać przy tym, że jedyne globalne maksimum funkcji $F_{N}$ występuje, gdy $\forall i: \delta_{i}=0$, ponieważ wtedy wszystkie jej człony osiągają maksymalną wartość $(\cos (\delta)=1)$. Szczegółowe wyniki dotyczące parametru porządku w podanych powyżej przypadkach są przedstawione w tab.1.1.

Ponieważ rozwiązania na różnice faz mają postać zależną od rozkładu częstości daną równaniami (1.15), to każde z wyliczonych ustawień jest możliwe tylko dla konkretnego rozkładu częstości. W szczególności istnieją układy, dla których rozwiązanie jest zsynchronizowane, natomiast nie zachodzi koherencja faz (tzn. $r \approx 0$ ). $\mathrm{Z}$ drugiej strony, widać że układy faz $\pm \delta$ odpowiadaja pewnym rozwiązaniom o zerowym nawinięciu ( $m=0)$ i mają stały, niezależny od $N$ parametr porządku.

Dodatkowo, dla ustawienia faz $\operatorname{co} \delta \in(0, \pi / 2)$, mamy $p=\sin \delta, \Delta_{i}=0$. Odpowiada to rozwiązaniom o wyższych nawinięciach dla rozkładu jednorodnego, tzn. $m=0,1,2, \ldots,\left\lfloor\frac{N}{4}\right\rfloor$. Wynikają stąd możliwe różnice faz: $\delta=0,2 \pi / N, 4 \pi / N, \ldots, 2 m \pi / N$. 


\begin{tabular}{c|ccl}
$\delta_{i}$ & $\mathrm{~N}$ & $\mathrm{r}$ & Rozkład \\
\hline & & & \\
0 & dowolne & 1 & $p=0, \Delta_{i}=0$ \\
$\pi / 2$ & $4 \mathrm{n}$ & 0 & $p=1, \Delta_{i}=0, \Delta_{1}=-\Delta_{N}=0$ \\
$\pi / 2$ & $4 \mathrm{n}+2$ & $\sqrt{2} / N$ & $p=1, \Delta_{i}=0, \Delta_{1}=-\Delta_{N}=-2$ \\
$\pi / 2$ & $2 \mathrm{n}+1$ & $1 / N$ & $p=1, \Delta_{i}=0, \Delta_{1}=-\Delta_{N}=-1$ \\
$\pm \delta$ & $2 \mathrm{n}$ & $\left|\cos \frac{\delta}{2}\right|$ & $p=\sin \delta, \Delta_{2 i}=-\Delta_{2 i+1}=2 \sin \delta$ \\
$\pm \delta$ & $2 \mathrm{n}+1$ & $\sqrt{\cos ^{2} \frac{\delta}{2}+\left(\sin ^{2} \frac{\delta}{2}\right) / N^{2}}$ & $p=\sin \delta, \Delta_{2 i+1}=-\Delta_{2 i}=2 \sin \delta, \Delta_{N}=0$
\end{tabular}

Tablica 1.1: $0, \pi / 2$ oznaczają w skrócie rozwiązania, gdzie wszystkie różnice faz równają się podanej wartości, a $\pm \pi / 2$ rozwiązania, dla których różnice faz równają się podanej wartości naprzemian z plusem i minusem. Wartości odchyleń od średniej $\Delta_{i}$ należy przemnożyć przez $k / 2$.

Ogólnie dla ustawień $\pi / l, l=1,2,3, \ldots$ da się policzyć parametr porządku $r$, aczkolwiek każdorazowo wymaga to rozpatrywania $l+1$ przypadków (dla różnego rozmiaru $N$ układu). Różnice te wynikają stąd, że ostatnia, „domykająca” różnica faz nie będzie się równać $\pi / l$, ale pewnej wielokrotności tej liczby. Przypuszczalnie wszystkim takim rozwiązaniom będzie odpowiadał $r \sim N^{-1}$ lub $r=0$ (przy czym dla większych $l$ będzie względnie mniej przypadków $r$ ściśle równym zeru). 


\section{Rozdział 2}

\section{Przykładowe rozwiazania modelu}

\section{lokalnego}

W tym rozdziale, za wyjątkiem 2.4, zebrane zostały przykłady układów o ustalonej liczbie oscylatorów oraz specjalnie dobranych częstościach własnych, dla których m.in. wyznaczono postać rozwiązań zsynchronizowanych, ich liczbę, wartości krytyczne stałej sprzężenia, zachowanie się parametru porządku czy wielkości basenów atrakcji. Z jednej strony mają one ułatwić pełne zrozumienie zagadnień przedstawionych w rozdz.1, a z drugiej dają także numeryczne potwierdzenie zawartych tam wyników.

Do analizy numerycznej używano w najprostszym razie metody punktu środkowego o kroku 1/16 i czasie oczekiwania 512 jednostek (tzn. 512 · 16 kroków), natomiast w wątpliwych wypadkach klasycznej czterokrokowej metody Rungego-Kutty o kroku nawet do 1/512 z czasem 4096 jednostek.

\section{1 $N=3$, dowolny rozkład częstości}

Pokażemy w prostym przypadku trzech oscylatorów, jak konstruuje się rozwiązania zsynchronizowane,

jak wygląda parametr porządku $r$ rozwiązania w zależności od wyboru rozkładu częstości, jak działa analiza stabilności na podstawie tw. Gerszgorina oraz jak wyglądają ograniczenia na rozkład częstości, aby synchronizacja w ogóle zachodziła.

Zauważmy, że wybór konkretnego układu oznacza wybór punktu $\left\{\omega_{1}, \omega_{2}, \omega_{3}\right\}$ w przestrzeni możliwych częstości własnych oscylatorów (równoważnie: $\left\{\Delta_{1}, \Delta_{2}, \Delta_{3}\right\}$, gdzie $\Delta_{i}=\omega_{i}-\Omega$ ) na płaszczyźnie $\omega_{1}+\omega_{2}+\omega_{3}=3 \Omega\left(\Delta_{1}+\Delta_{2}+\Delta_{3}=0\right)$. Rozwiązania na różnice faz sąsiadujących zsynchronizowanych 
oscylatorów dane są przez układ równań:

$$
\begin{aligned}
& \phi_{3}-\phi_{2}=\arcsin p \\
& \phi_{2}-\phi_{1}=\arcsin \left(p+\frac{2}{k} \Delta_{2}\right) \\
& \phi_{1}-\phi_{3}=\arcsin \left(p+\frac{2}{k} \Delta_{1}+\frac{2}{k} \Delta_{2}\right)=\arcsin \left(p-\frac{2}{k} \Delta_{3}\right) .
\end{aligned}
$$

Na podstawie tw. Gerszgorina przypuszczamy, że dla układu o $N=3$ nie istnieją rozwiązania o liczbie nawinięć wyższej niż $m=0$, gdyż różnice fazowe musiałyby przekraczać $\pi / 2$. Rzeczywiście, pomimo niezupełnej dokładności tego oszacowania, z rys.2.1 wynika, że nie da się znaleźć stabilnego układu różnic fazowych, które systematycznie narastałyby dając $\pm 2 \pi$. A więc powyższy układ równań, po zsumowaniu stronami daje warunek

$$
\arcsin (p)+\arcsin \left(p+\frac{2}{k} \Delta_{2}\right)+\arcsin \left(p-\frac{2}{k} \Delta_{3}\right)=0
$$

Równanie to wyznacza dwuwymiarowy obszar, przedstawiony na rys.2.2 w przestrzeni $\left\{\Delta_{1}, \Delta_{2}, \Delta_{3}\right\}$ parametryzowany $p$ (tj. parametrem rozwiązania układu liniowego (1.12)). Określa on, dla jakich rozkładów częstości (równoważnie, dla jakich stałych sprzężenia $k$ ) w ogóle istnieje rozwiązanie zsynchronizowane. Dla danego rozkładu tylko jedna wartość parametru $p$ daje możliwe rozwiązanie. (Ogólnie, dla układu o danym $N$, każdy z warunków o danej liczbie nawinięć $m$ może wyznaczać $N-1$ wymiarowe obszary wyznaczające rozkłady posiadające rozwiązania zsynchronizowane. $Z$ podanych wcześniej argumentów wynika, że w granicy $N \rightarrow \infty$ obszar rozkładów częstotliwości zdolnych do synchronizowania jest miary zero.)

Można teraz wyznaczyć postać parametru porządku $r$. Funkcja podana w (1.23) i $r$ przyjmują w tym wypadku postać

$$
\begin{aligned}
F_{3}\left(\delta_{1}, \delta_{2}\right) & =3+2 \cos \delta_{1}+2 \cos \delta_{2}+2 \cos \left(\delta_{1}+\delta_{2}\right) \\
r & =\frac{\sqrt{F_{3}}}{3},
\end{aligned}
$$

gdzie dla ustalenia uwagi $\delta_{1} \equiv \phi_{1}-\phi_{3}$ i $\delta_{2} \equiv \phi_{2}-\phi_{1}$ (w zasadzie, możemy wybrać dowolne dwie różnice fazowe). Zachowanie się $r$ w zależności od wyboru częstości własnych ilustruje rys.2.3.

Widać, że najmniejszym $F_{3}$ oraz $r$ odpowiada

$$
\begin{aligned}
F_{3}^{\min } & =F_{3}\left( \pm \frac{\pi}{2}, \pm \frac{\pi}{2}\right)=1 \\
r_{\text {min }} & =\frac{\sqrt{F_{3}^{\min }}}{3}=\frac{1}{3}
\end{aligned}
$$




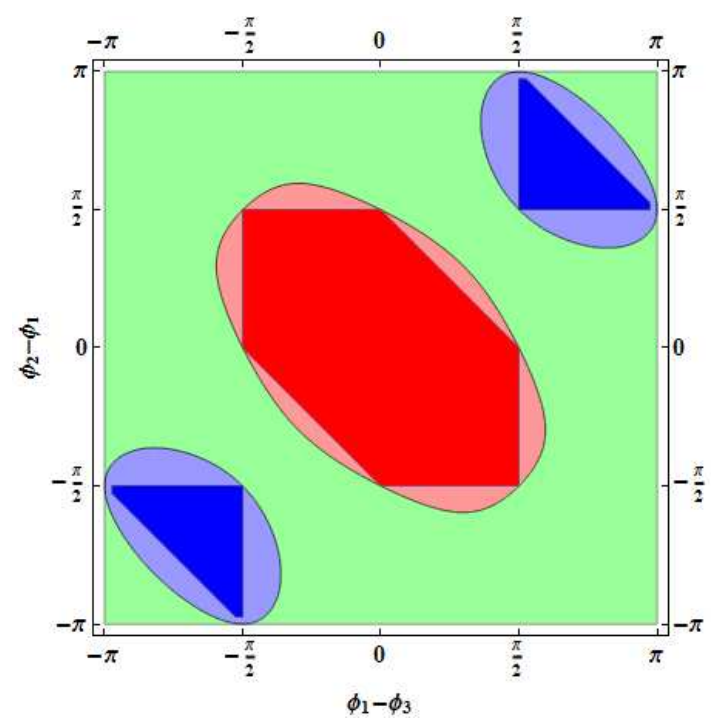

Rysunek 2.1: Obszar czerwony to rozwiązania stabilne, niebieski i zielony - niestabilne odpowiednio ze względu na 2 i 1 wartość własną. Kolorami ciemnymi zaznaczono obszary wyznaczone przy pomocy tw. Gerszgorina.

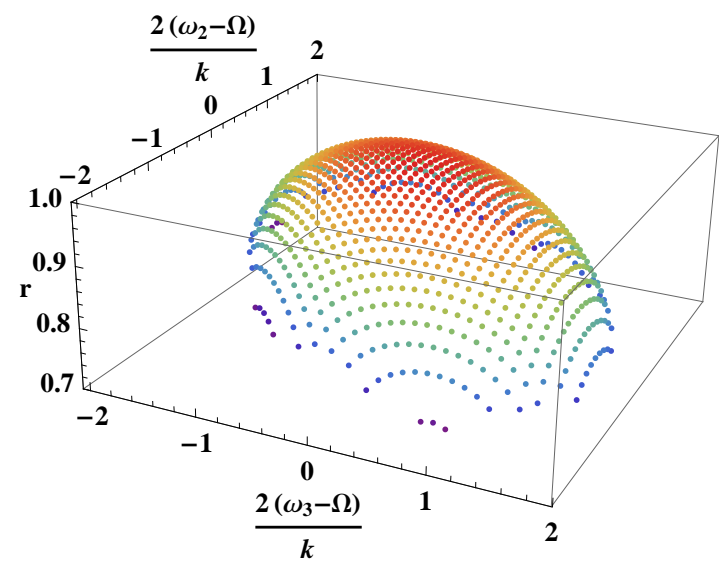

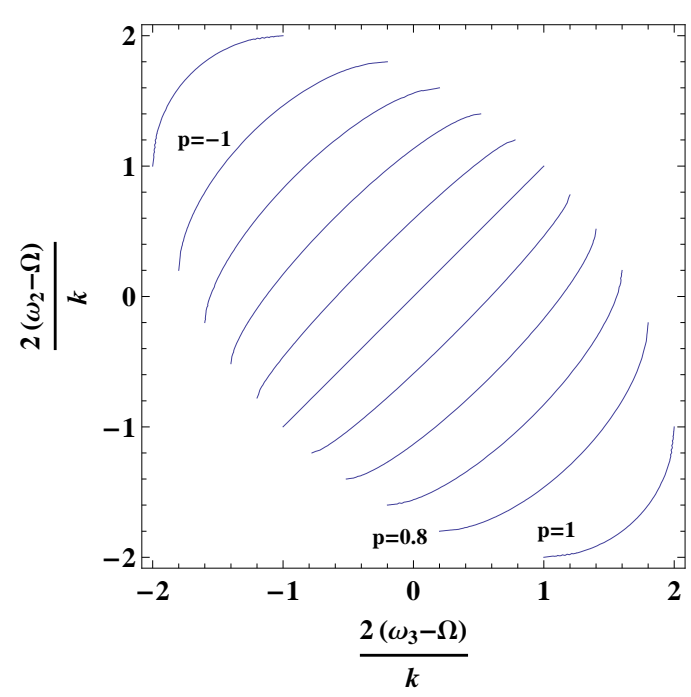

Rysunek 2.2: Obszar istnienia rozwiązań na płaszczyźnie $\left\{\Delta_{2}, \Delta_{3}\right\}$. Kolejne krzywe są narysowane dla wartości parametru $p=-1,-0.8,-0.6, \ldots, 0.8,1$.

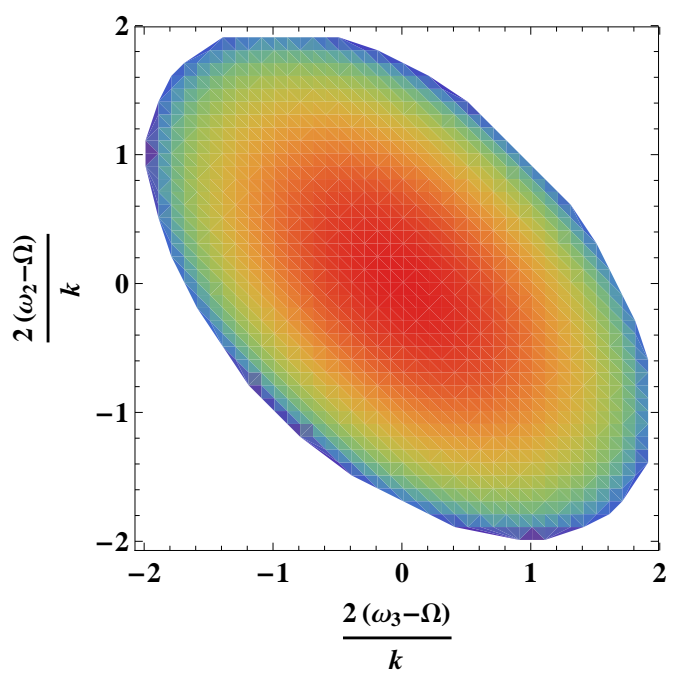

Rysunek 2.3: Parametr $r$ rozwiązania zsynchronizowanego w zależności od układu (wyboru częstości własnych oscylatorów) dla $N=3$. Należy zwrócić uwagę na zakres $r$. 
(przy czym jest to rozwiązanie neutralnie stabilne), natomiast największym

$$
\begin{aligned}
& F_{3}^{\max }=F_{3}(0,0)=9 \\
& r_{\text {max }}=\frac{\sqrt{F_{3}^{\max }}}{3}=1 .
\end{aligned}
$$

Metodą czynników Lagrange’a dla rozwiązań stabilnych rzeczywiście dostaje się jedyne ekstremum globalne dla

$$
\begin{gathered}
\delta_{1}=\delta_{2}=\delta_{3}=0 \Leftrightarrow \phi_{1}=\phi_{2}=\phi_{3} \\
r_{\max }=1,
\end{gathered}
$$

tzn. przy spełnionych warunkach

$$
\begin{aligned}
\arcsin p & =0 \\
\arcsin \left(p+\Delta_{2}\right) & =0 \\
\arcsin \left(p-\Delta_{3}\right) & =0,
\end{aligned}
$$

co pociąga za sobą:

$$
p=\Delta_{1}=\Delta_{2}=\Delta_{3}=0
$$

Oznacza to oczywiście, że pełna synchronizacja ( $r=1$ ściśle, czyli całkowita „koherencja faz”) w układzie 3 oscylatorów jest możliwa jedynie wtedy, gdy wszystkie trzy częstości własne są równe.

\section{2 $N=5$ : rozwiązania stabilne, parametr porządku, $k_{c}$, liczby nawinięć}

Rozważam układ o $N=5$ i rozkładzie częstości własnych $\omega_{1}=1 / 4, \omega_{2}=-1 / 4, \omega_{3}=0, \omega_{4}=0$, $\omega_{5}=0$. Średnia częstość jest ustalona $\Omega=0$. $Z$ nierówności (1.9) widać, że mamy pierwsze oszacowanie na krytyczną stałą sprzężenia $k_{c} \geq 1 / 4$. Równanie (1.16) przybiera postać

$$
4 \arcsin (p)+\arcsin \left(p-\frac{1}{2 k}\right)=2 m \pi,
$$

gdzie $m=-1,0,+1$, jak podano w (1.17), oraz $p$ jako argument funkcji arcus sinus musi przyjmować wartości $p \in[-1,1] \cap[-1+1 /(2 k), 1+1 /(2 k)]=[-1+1 /(2 k), 1]$.

Zmiana liczby pierwiastków tego równania wraz ze zmianą $k$ jest zilustrowana na rys.2.4. Widać, że można otrzymać $0,1,2$ lub 3 rozwiązania w zależności od sprzężenia. Analogicznie można otrzymać rozwiązania niestabilne. $\mathrm{Z} 2^{4}=16$ różnych wyborów postaci odwikłania różnic fazowych otrzymuje się w tym wypadku 10 różnych równań (w ogólności dla innych rozkładów może być też $2^{N-1}$ równań), przykładowo

$$
2 \pi+2 \arcsin (p)-\arcsin \left(p-\frac{1}{2 k}\right)=2 m \pi,
$$




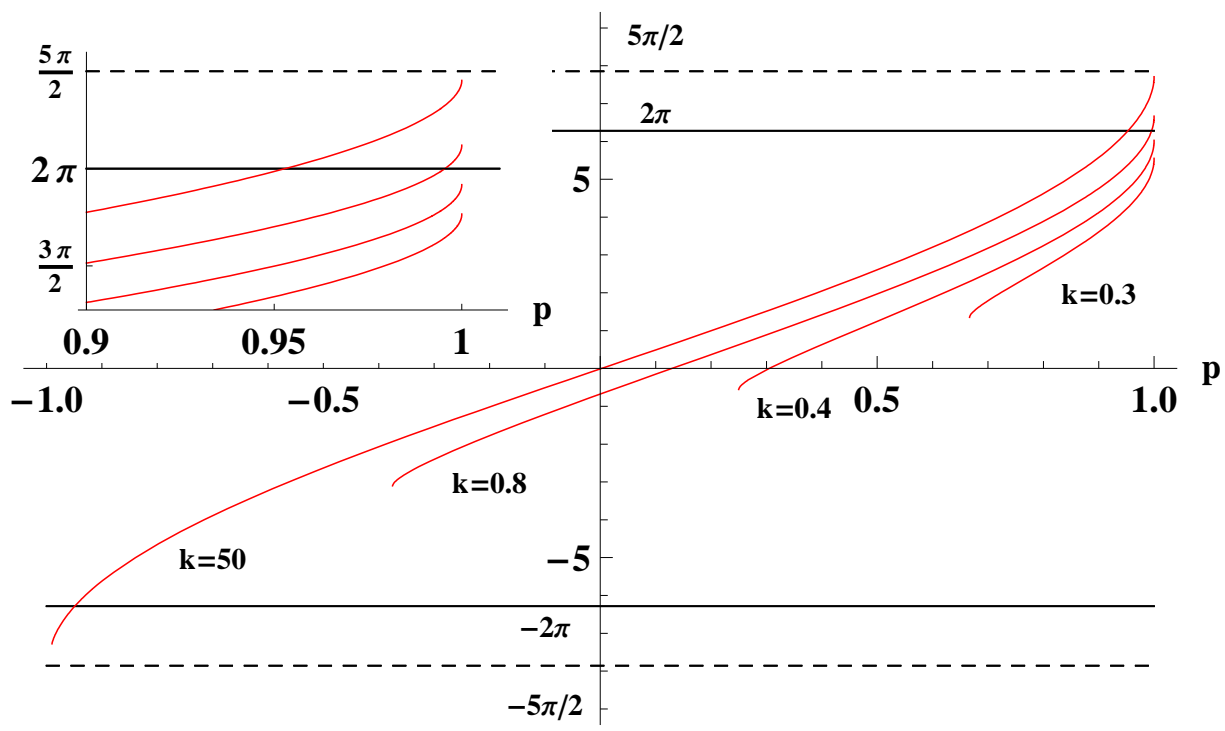

Rysunek 2.4: Wykres lewej strony równania (2.9): $L=4 \arcsin (p)+\arcsin (p-1 /(2 k))$.

Przecięcia z 0 i $\pm 2 \pi$ wyznaczają $p$ i ustalają rozwiązania. Dla kolejnych wartości sprzężenia $k$ otrzymuję $0,1,2$ lub 3 rozwiązania. Linie przerywane wyznaczają maksymalną możliwą wartość $L($ dla $k \rightarrow \infty)$.

którego lewa strona jest niemonotoniczna i który może mieć 1 lub 2 pierwiastki dla $m=1$.

Jesteśmy w stanie policzyć wartości $k$, dla których pojawiają się kolejne pierwiastki równania (2.9). W tym celu obliczam zakres wartości jego lewej strony - ponieważ jest ona monotonicznie rosnącą funkcją $p$ otrzymuje się

$$
L \in\left[4 \arcsin \left(\frac{1}{2 k}-1\right)-\pi / 2,2 \pi+\arcsin \left(1-\frac{1}{2 k}\right)\right] .
$$

Należy teraz wyznaczyć, dla jakich wartości $k$ końce tego przedziału przyjmują wartości $-2 \pi, 0,2 \pi$. Dostaje się

$$
\begin{aligned}
k_{m=-1} & =\frac{1}{2(1-\sin (3 \pi / 8))} \approx 6.57 \\
k_{m=1} & =1 / 2 \\
k_{m=0} & =\frac{1}{2(1+\sin (\pi / 8))} \approx 0.36 .
\end{aligned}
$$

Powyżej najwyższej z tych wartości, tj. dla silnych sprzężeń, występują w zależności od wyboru warunków początkowych wszystkie 3 stabilne rozwiązania zsynchronizowane, natomiast poniżej $k \approx 0.36$ takie rozwiązania w ogóle nie istnieją. Należy więc w tym przypadku przyjąć za krytyczną wartość stałej sprzężenia

$$
k_{c}=k_{m=0} \approx 0.36
$$




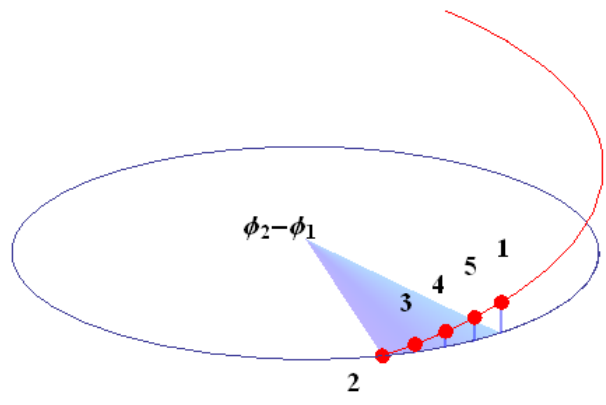

(a)

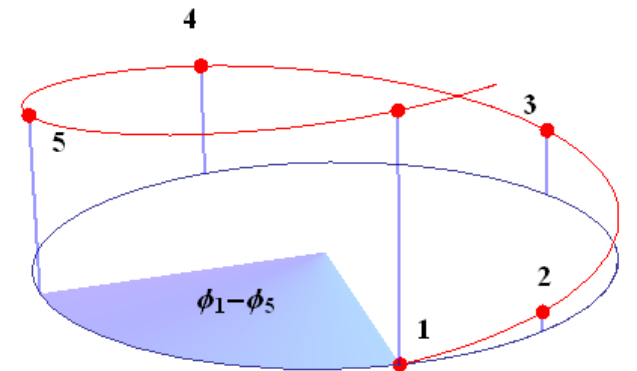

(b)

Rysunek 2.5: Rozwiązania stabilne dla $k=1$, bez i z 1 nawinięciem, odpowiednio (a) i (b). Zaznaczono kolejność oscylatorów i przykładowe różnice faz.

Aby zilustrować, jak wyglądają rozwiązania ze względu na różnice faz, obliczymy je dla przypadku $k=1$. Z rys.2.4 widać, że otrzymuje się dwa rozwiązania ze względu na $p$ (podaję przybliżone wartości numeryczne), które dają rozkłady różnic fazowych bez nawinięcia i z jednym nawinięciem, co zobrazowane zostało na rys.2.5:

$$
p \approx \begin{cases}0.102 & \text { dla } m=0 \\ 0.992 & \text { dla } m=1\end{cases}
$$

Po podstawieniu wartości $p$ i $\Delta_{i}$ do równań (1.15) i otrzymuje się dwa rozwiązania stabilne:

$$
\begin{array}{ll}
m=0: & m=1: \\
\phi_{5}-\phi_{4}=\arcsin p=0.102 & \phi_{5}-\phi_{4}=\arcsin p=1.442 \\
\phi_{4}-\phi_{3}=\arcsin (p)=0.102 & \phi_{4}-\phi_{3}=\arcsin p=1.442 \\
\phi_{3}-\phi_{2}=\arcsin (p)=0.102 & \phi_{3}-\phi_{2}=\arcsin p=1.442 \\
\phi_{2}-\phi_{1}=\arcsin (p-1 / 2)=-0.409 & \phi_{2}-\phi_{1}=\arcsin (p-1 / 2)=0.514 \\
\phi_{1}-\phi_{5}=\arcsin (p)=0.102 & \phi_{1}-\phi_{5}=\arcsin p=1.442 .
\end{array}
$$

W ogólności, stabilne rozwiązania są dane przez

$$
\begin{aligned}
\phi_{1}-\phi_{5}=\phi_{5}-\phi_{4}=\phi_{4}-\phi_{3}=\phi_{3}-\phi_{2} & =\arcsin p^{*}(k) \\
\phi_{2}-\phi_{1} & =\arcsin \left(p^{*}(k)-\frac{1}{2 k}\right),
\end{aligned}
$$

gdzie $p^{*}(k)$ jest pewnym pierwiastkiem równania (2.9).

Interesujące jest pytanie, jakie są wielkości basenów atrakcji rozwiązań o różnych $m$. Ze względu na spory koszt numeryczny zrobiono to dla $7^{4}=2401$ warunków początkowych (różnice faz zawierają 
się w przedziale $[-\pi, \pi]$, który podzielono siedmioma punktami; dostajemy $N-1=4$ niezależnych różnic faz). Wyniki przedstawione są na rys.2.6. Oba rozwiązania z niezerowym nawinięciem zajmują niewielką część przestrzeni w stosunku do rozwiązań $m=0$, a wielkość ich basenów atrakcji jest niemal identyczna dla sprawdzonego zakresu sprzężeń. Temu zachowaniu towarzyszą większe (bliższe zeru) maksymalne wartości własne macierzy zaburzenia dla rozwiązań $\pm m$, jak zilustrowano na rys.2.7.

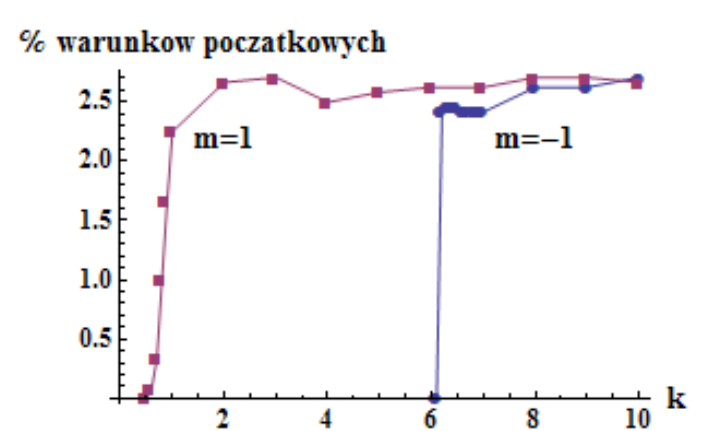

Rysunek 2.6: Procentowa ilość warunków początkowych wiodących do rozwiązań $m= \pm 1$. Pozostałe warunki przynależą do rozwiązania $m=0$.

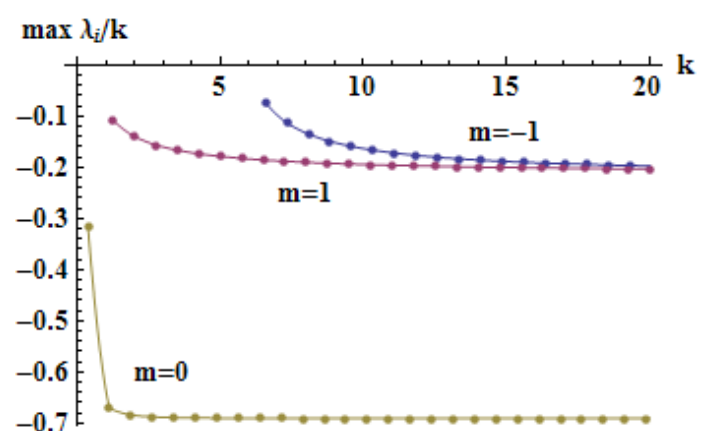

Rysunek 2.7: Zależność maksymalnej niezerowej wartości własnej $\lambda$ macierzy zaburzenia od sprzężenia $k$ (po usunięciu zależności liniowej). Punkty obliczone numerycznie wraz z krzywymi interpolującymi.

Można teraz wyliczyć, korzystając ze wzoru (1.23), parametr porządku $r$, zależny od czterech z powyższych różnic fazowych. Wynik da się zapisać następująco:

$$
\begin{aligned}
\delta_{\phi} & \equiv \arcsin p^{*} \\
F_{5}\left(\delta_{\phi}\right) & =5+2\left(4 \cos \left(\delta_{\phi}\right)+3 \cos \left(2 \delta_{\phi}\right)+2 \cos \left(3 \delta_{\phi}\right)+\cos \left(4 \delta_{\phi}\right)\right)= \\
& =13+16 p^{* 4}+12 \sqrt{1-p^{* 2}}-4 p^{* 2}\left(7+4 \sqrt{1-p^{* 2}}\right) \\
r & =\left(\sqrt{F_{5}\left(\delta_{\phi}\right)} / 5\right) .
\end{aligned}
$$

Oczywiście problemem jest niemożność odwikłania wzoru na $p^{*}$, korzystać trzeba z numerycznie wyznaczonych pierwiastków.

Zachowanie się $r$ w zależności od $k$ obrazuje rys.2.8. Dla sprzężenia $k>k_{c}$ narysowano parametr porządku zgodnie z wyliczeniami analitycznymi, całkowicie zgodny z rozwiązaniami numerycznymi (tzn. układ, dla różnych warunków początkowych, po pewnym czasie zawsze dochodził do rozwiązań analitycznych i do żadnych innych). Warto zauważyć, że rozwiązanie dla $m=1$ znika (przy malejącym k) dla ustawienia faz oscylatorów co $\pi / 2$ - był to przykład podany w tab.1.1.

Poniżej progu synchronizacji pionowymi kreskami zaznaczono na wykresie zbiory rozwiązań numerycznych dla różnych warunków początkowych. Ponadto, układ poniżej progu synchronizacji nie 


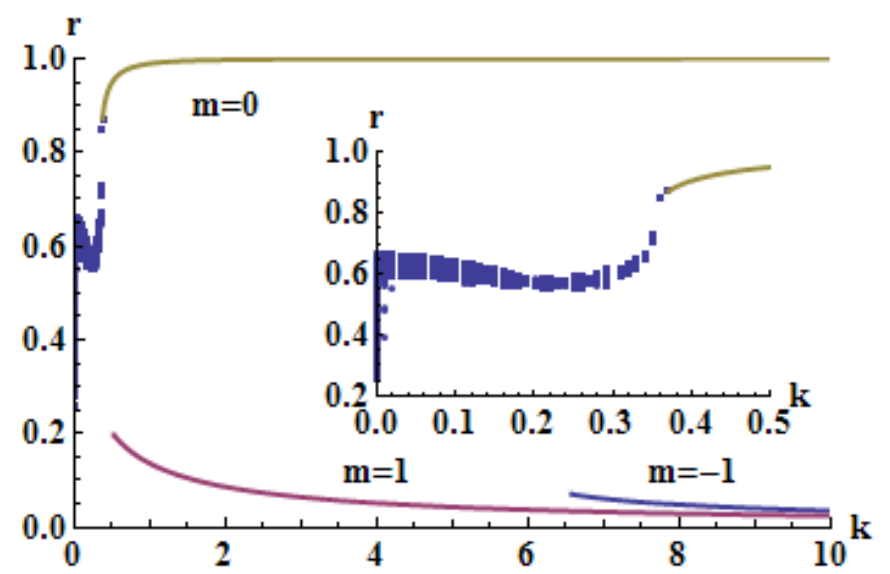

Rysunek 2.8: Zachowanie parametru porządku $r$ w zależności od sprzężenia $k$. Okienko pokazuje zależne od warunków początkowych wartości numeryczne, gdy $k<k_{c}$, skąd „rozmycie” wykresu.

dochodzi do stanu stacjonarnego, ale zachowuje się periodycznie. Dlatego na wykresie pokazano jedynie wartości $r$ uśrednione po pewnym czasie dłuższym od okresu zachowania układu. „Rozmycie” średniej może być także częściowo spowodowane niedokładnym sposobem jej obliczania (urywanie średniowania w różnych momentach względem okresu).

Przykładowe przebiegi zachowania się parametru porządku w czasie, poniżej i w pobliżu $k_{c}$, przedstawia rys.2.9. Tuż poniżej $k_{c}$ pojawia się zachowanie periodyczne (tzw. „phase slips” i ,frequency firings" opisane w [29, 30]), którego okres wzrasta do nieskończoności wraz ze zbliżaniem się do progu.

W klasycznym modelu Kuramoto krytyczna wartość sprzężenia była definiowana przez pojawienie się niezerowej wartości parametru porządku $r$. W przypadku lokalnego układu na okręgu istnieją rozwiązania o $r \approx 0$, które są zsynchronizowane (na wykresach widać, że parametr porządku przyjmuje wartości niezerowe, ale dla układu o $N \rightarrow \infty$ spodziewamy się $r \rightarrow 0$ ). Układ zsynchronizowany zatem odróżnia się od niezsynchronizowanego przede wszystkim jednakową częstością poszczególnych oscylatorów, co pociąga za sobą istnienie stanu stacjonarnego (,phase-locked”).

\section{3 $N=6$ : kontrprzykład na pojawianie się jako pierwsze $m=0$, zachowanie parametru porządku i wartości własnych}

Wydaje się, że rozwiązania bez nawinięcia $(m=0)$ są jakoś wyróżnione; charakteryzuje je wysoka wartość parametru porządku oraz, w szczególności, to ich pojawienie się definiuje wartość $k_{c}$ (tzn. są to 

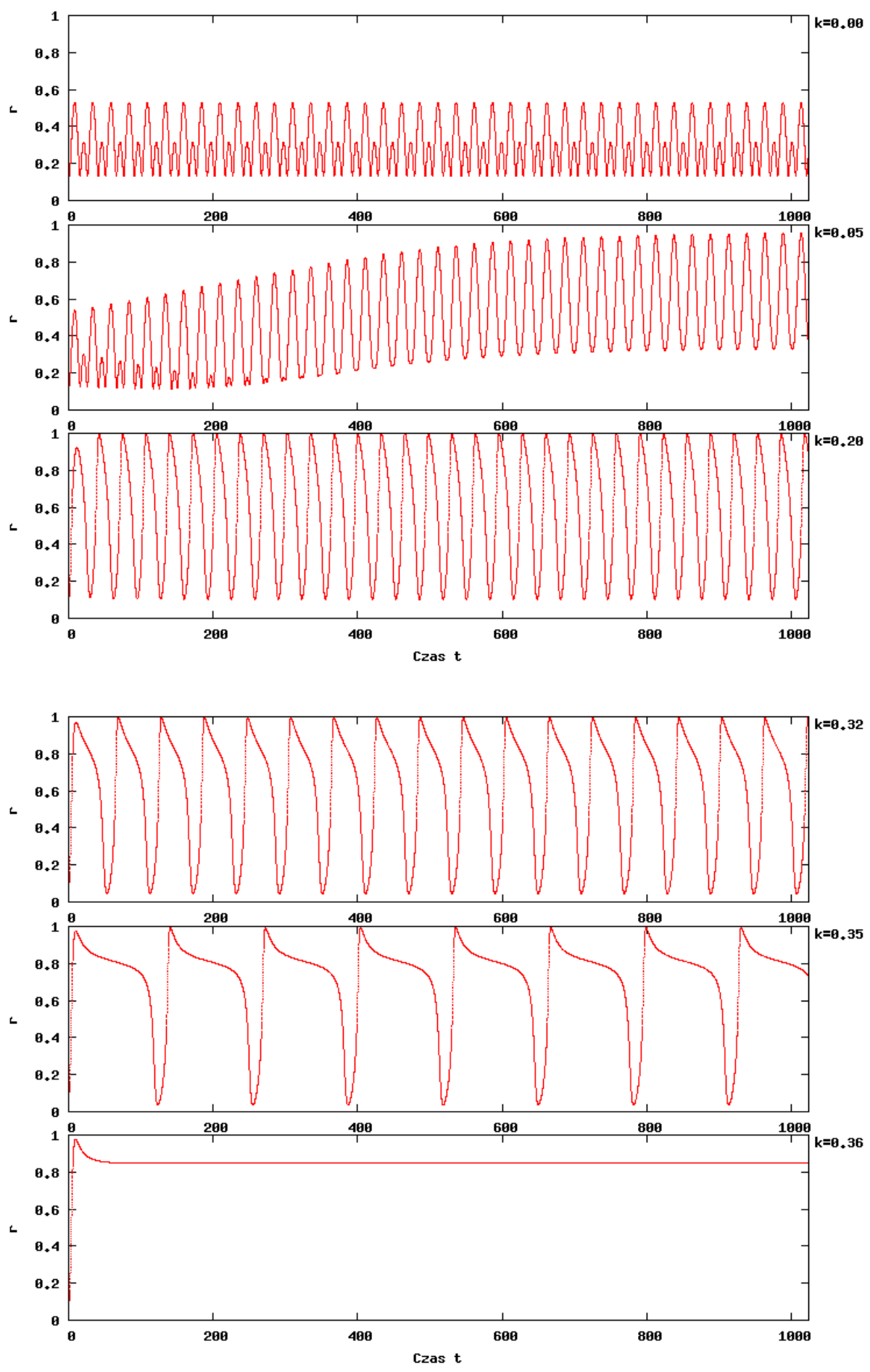

Rysunek 2.9: Przebieg parametru porządku $r$ w czasie dla różnych wartości $k$. Widać oscylacyjne zachowanie poniżej $k_{c} \approx 0.36$ oraz wydłużenie okresu dla $k$ bliskich $k_{c}$. Wykresy dla warunku początkowego $(0,-2.1,-2.1,0.9,2.9)$. 


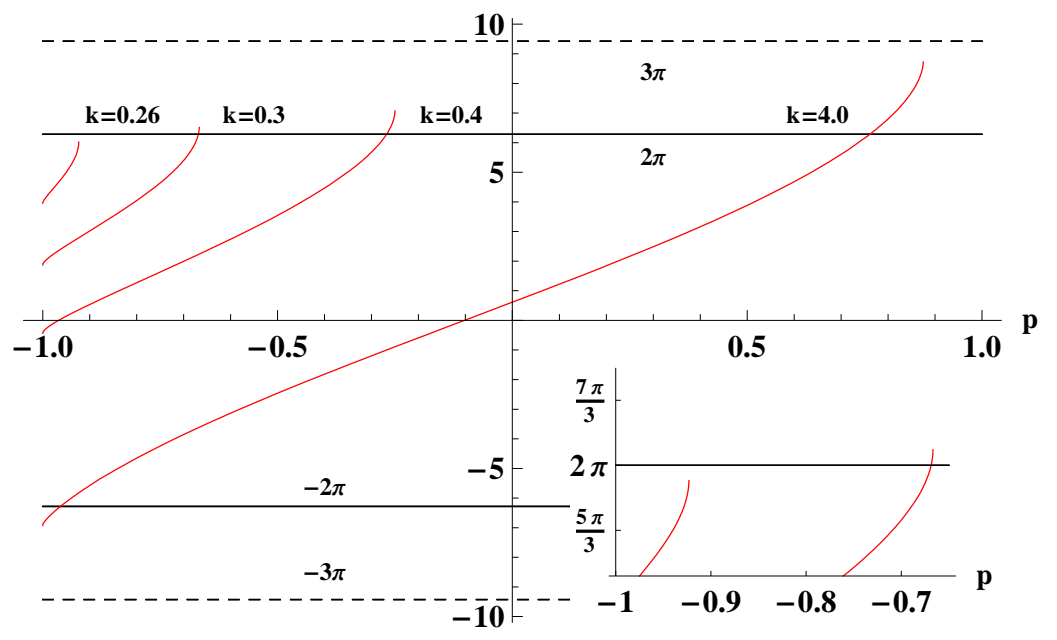

Rysunek 2.10: Wykres lewej strony równania (2.18): $\arcsin (p)+\arcsin \left(p+\frac{9}{20 k}\right)+$ $4 \arcsin \left(p+\frac{1}{2 k}\right)$. Zwiększając $k$ (patrząc od lewej) pierwsze pojawia się przecięcie $\mathrm{z} 2 \pi$, czyli rozwiązanie o $m=1$.

rozwiązania pojawiające się najwcześniej przy wzroście stałej sprzężenia). Okazuje się, że w ogólności tak nie jest. Pokażemy na poniższym przykładzie, że pierwsze może pojawić się rozwiązanie z wyższą liczbą nawinięć.

Rozpatrujemy układ o $N=6$ oraz rozkładzie częstości własnych $\omega_{1,2,3}=0, \omega_{4}=1 / 40, \omega_{5}=9 / 40$, $\omega_{6}=-1 / 4$, przy średniej $\Omega=0$. Pierwsze oszacowanie daje $k_{c} \geq 1 / 4$. Układ posiada rozwiązania o co najwyżej \pm 1 nawinięciu. Równanie (1.16) przyjmuje postać

$$
\arcsin (p)+\arcsin \left(p+\frac{9}{20 k}\right)+4 \arcsin \left(p+\frac{1}{2 k}\right)=2 m \pi
$$

Dostajemy wartości sprzężenia, dla których pojawiają się kolejne rozwiązania,

$$
\begin{aligned}
k_{m=0} & \approx 0.375 \\
k_{m=1} & =0.275 \\
k_{m=-1} & \approx 2.565,
\end{aligned}
$$

z których najmniejsze jest $k_{c}=k_{m=1}$.

Na rys.2.11 i 2.12 pokazana jest dla tych rozwiązań zależność $r(k)$ oraz zależność największej niezerowej wartości własne macierzy zaburzenia od $k$.

Parametr porządku można prosto wyliczyć z poniższego wzoru (ze względu na 3 różne od zera częstości własne rozwiązanie będzie się składać z 3 różnych różnic fazowych, z czego tylko dwie będa 
niezależne, więc i $r$ zależne jest jedynie od dwu różnic fazowych)

$$
\begin{gathered}
F_{6}\left(\delta_{1}, \delta_{2}\right)=6+2 \sum_{j=1}^{4}(5-j) \cos \left(j \delta_{1}\right)+2 \sum_{j=0}^{4} \cos \left(j \delta_{1}+\delta_{2}\right) \\
r\left(\delta_{1}, \delta_{2}\right)=\sqrt{F_{6}\left(\delta_{1}, \delta_{2}\right)} / 6 \\
\text { gdzie } \quad \delta_{1}=\arcsin \left(p+\frac{1}{2 k}\right) \\
\delta_{2}=\arcsin (p)
\end{gathered}
$$

Wydaje się, że dla dużych sprzężeń $m=0$ pozostaje jednak rozwiązaniem dominującym (w sensie wielkości basenu atrakcji) oraz oczywiście tylko dla niego może zachodzić pełna koherencja faz. Koresponduje to $\mathrm{z}$ argumentami podanymi w rozdz.1.3.

Numeryczna analiza tego przypadku każe poczynić pewne szczegółowe uwagi. Po pierwsze, basen atrakcji kolejnych pojawiających się wraz ze wzrostem $k$ rozwiązań rośnie „,szybko” do pewnego skończonego, prawie stałego rozmiaru - oczywiście, nie jesteśmy w stanie przeanalizować numerycznie ciągłego zakresu $k$. Kiedy istniejące już rozwiązania ściągają wszystkie warunki początkowe, następne pojawiające się rozwiązanie zabiera część basenu atrakcji innym.

Jednakże w przypadku tutaj opisanym, kiedy rozwiązanie $m=1$ istnieje jako pierwsze, widzi się coś jeszcze: rozwiązanie to, mimo że jest jedyne, może mieć zarówno bardzo niewielki, jak i obejmujący całą przestrzeń warunków początkowych basen atrakcji, co ilustruje rys.2.13. Skoro rozwiązanie to jest liniowo stabilne ze względu na małe zaburzenia, to układ po pewnym czasie powinien do niego dojść, zaczynając od dowolnych, bliskich temu rozwiązaniu warunków początkowych (pamiętać należy, że dla oddalonych warunków początkowych związek pomiędzy wartościami własnymi macierzy zaburzenia i wielkością basenów atrakcji pozostaje jedynie przypuszczeniem). Tutaj obserwujemy przypadki, w których pewne warunki początkowe prowadzą do jakiegoś periodycznego i niezsynchronizowanego zachowania układu.

Dopiero po pojawieniu się rozwiązania o $m=0$ takie warunki początkowe dają synchronizację. Problem ten pojawia się w pobliżu wartości krytycznych parametru $k$, tj. tam, gdzie rozwiązanie $m=1$ ma zniknąć bądź gdzie $m=0$ ma się pojawić. W pobliżu $k_{m=0}$ najprawdopodobniej rozwiązania są ściągane do ,prawie istniejącego” stanu zsynchronizowanego bez nawinięć, a trajektorie prowadzące do rozwiązania $m=1$ są łatwo destabilizowane.

Wyjaśnić ten fakt można następująco: jak widać na rys.2.12 największa wartość własna rozwiązania $m=1$ jest relatywnie mała w interesującym nas zakresie sprzężeń, co oznacza, że układ dłużej powraca do tego rozwiązania po zaburzeniu. Możemy więc mieć do czynienia jedynie z efektem błędów numerycznych, które stale zaburzają układ i powodują, że nie może on dojść do stanu zsynchronizowanego lub znacząco wydłużają czas, który jest do tego potrzebny. Przemawia za tym znalezienie pewnych 


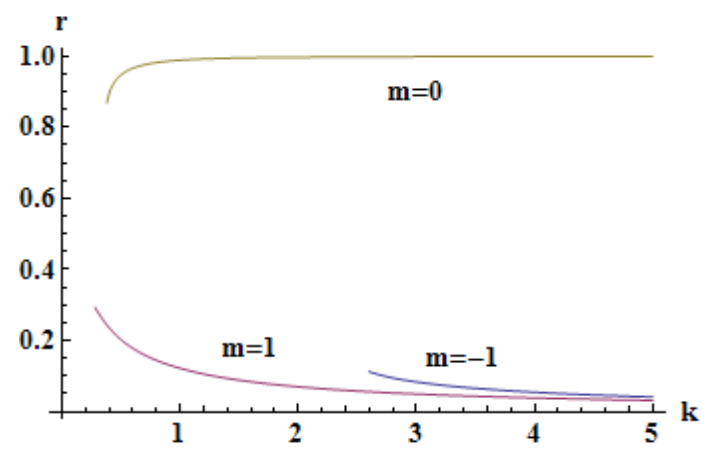

Rysunek 2.11: Parametr porządku $r(k)$ wyliczony analitycznie. Jako pierwsze pojawia się rozwiązanie $\mathrm{z} m=1$.

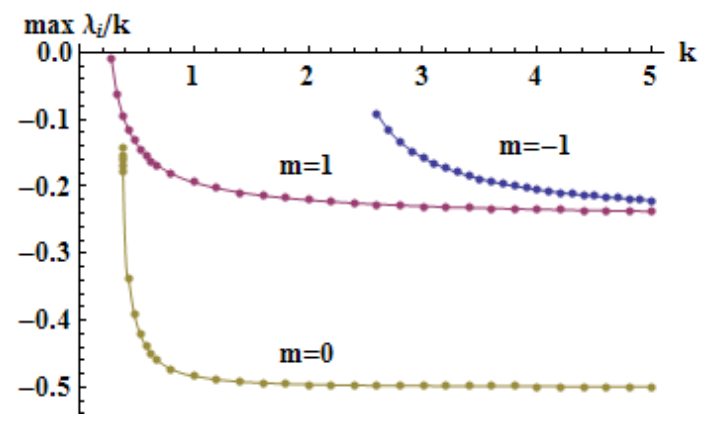

Rysunek 2.12: Wartości własne macierzy zaburzenia dla rozwiązań o różnej liczbie nawinięć.

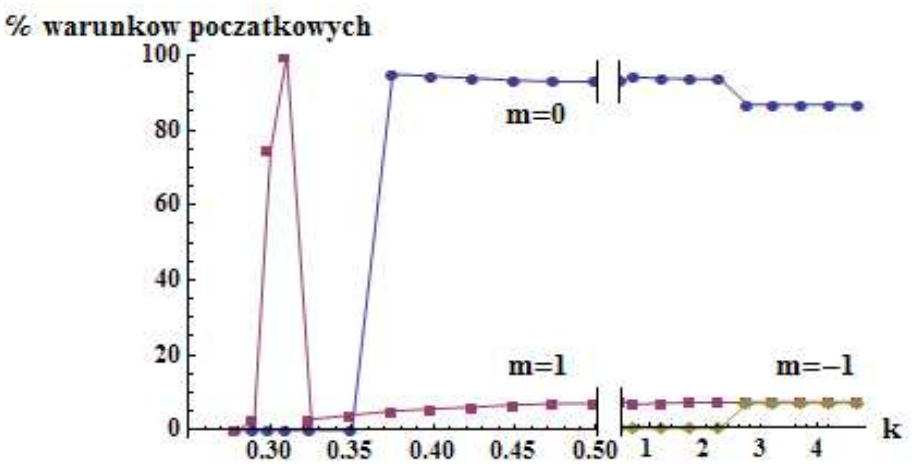

Rysunek 2.13: Wielkość basenów atrakcji przykładu $N=6$. Rozwiązanie $m=-1$ pojawia się pierwsze $\mathrm{w} k$, przyciąga wszystkie warunki początkowe, gdy $k=0.31$. Gdy $k=0.325,0.35$, rozwiązanie $m=0$, choć nie istnieje, powoduje pojawienie się dużego basenu rozwiązań niestacjonarnych. Dla $k=2.75$ rozwiązanie $m=-1$ odbiera część basenu atrakcji $m=0$. 
przypadków granicznych, dla których zmiana kroku metody numerycznej na mniejszy prowadziła do zmiany rozwiązania z owego niezsynchronizowanego na wyliczone w teorii rozwiązanie $m=1$.

Zasadniczo innym wyjaśnieniem, choć mniej prawdopodobnym w świetle przedstawionej powyżej argumentacji, byłoby istnienie rozwiązań niestacjonarnych wyjściowego układu równań różniczkowych (1.1). Innymi słowy, mogą po prostu istnieć warunki początkowe, które nie prowadzą do stabilnych, stacjonarnych rozwiązań, bez względu na precyzję numeryczną.

\section{4 $N$ dowolne: rozkłady zachowujące synchronizację przy $N \rightarrow \infty$}

Przy rozważaniu równania (1.16) przekonaliśmy się, że gdy $\max _{1 \leq i \leq N}\left|\sum_{j=1}^{i} \Delta_{j}\right|>k / 2$, rozwiązanie zsynchronizowane nie istnieje, przez co nieskończone układy o losowych rozkładach częstości nie mogą się synchronizować, gdyż sprzężenie musiałoby rosnąć proporcjonalnie do $N^{1 / 2}$.

$\mathrm{Z}$ drugiej strony jednak, da się zadać czy też skonstruować takie układy o nieskończonym $N$, które synchronizują się. Najprościej wybrać rozkład częstości typu $\Delta_{2 i}=-\Delta_{2 i+1}=\Delta$, który oczywiście powyższe ograniczenie spełnia $\left(\max _{1 \leq i \leq N}\left|\sum_{j=1}^{i} \Delta_{j}\right|=|\Delta|<\infty\right)$ oraz, jak pokazano w tab.1.1, ma stały w $N$ parametr porządku. W prosty sposób można nawet pokazać, że dla takiego układu $k_{c}=\Delta$.

Przypadek ten można teraz uogólnić: weźmy $n$ kolejno ustawianych na okręgu populacji typu $\pm \widetilde{\Delta}_{l}$, gdzie $l=1,2, \ldots, n$ charakteryzuje daną populację, która zawiera $N_{l}$ oscylatorów. Jeśli wszystkie $N_{l}$ są parzyste, to widać, że na końcu każdego podłańcucha suma odchyleń od średniej będzie się zerować, a więc nawet dla liczby oscylatorów $N \rightarrow \infty$ oraz liczby populacji $n \rightarrow \infty$ synchronizacja będzie możliwa dla skończonej stałej sprzężenia $k$. Pamiętać jednak należy o wniosku z równania (1.9), gdzie powiedzieliśmy, że rozkład częstości własnych musi być skończony (tzn. bez „ogonów”).

$\mathrm{Z}$ drugiej strony, jeśli takie klastry miałyby $N_{l}$ nieparzyste, to kolejne sumy $\sum_{j=1}^{i} \Delta_{j}, i=1, \ldots, N$ byłyby zmienione na $\sum_{l=1}^{i} \widetilde{\Delta}_{l}, i=1, \ldots, n$. Dla $n \rightarrow \infty$ doszlibyśmy więc do identycznego problemu, jak wcześniej.

W zasadzie, należy wskazać, że odpowiednie rozkłady konstruujemy nie w oparciu o odchylenia $\pm \widetilde{\Delta}_{l}$, lecz o częstości własne i ich średnią. Przyjmując bez straty ogólności $\Omega=0$ dostaje się symetrycznie rozłożone wokół średniej częstości kolejnych populacji $\pm \widetilde{\omega}_{l}$.

Mimo szczególności takich układów, należy podkreślić, że dają one nietrywialne rozwiązania, a równocześnie wykazują synchronizację w granicy termodynamicznej $N \rightarrow \infty$. 


\section{Rozdział 3}

\section{Sprzężenie modyfikowane,}

\section{asymetryczne}

Rozważamy układ, gdzie sprzężenie pomiędzy oscylatorami zmodyfikowane jest poprzez dodanie stałej do różnic fazowych

$$
\dot{\theta}_{i}(t)=\omega_{i}-\frac{k}{2}\left[\sin \left(\theta_{i}(t)-\theta_{i-1}(t)+\alpha\right)+\sin \left(\theta_{i}(t)-\theta_{i+1}(t)+\alpha\right)\right],
$$

gdzie $i=1, \ldots, N, \alpha \in[0, \pi / 2]$. W modelu średniego pola wprowadzono analogiczną modyfikację [19], zauważając potrzebę modelu bliższego rzeczywistości, to jest takiego, w którym oscylatory sprzęgają się do wspólnej częstości $\Omega$ różnej od zwykłej średniej ich częstości własnych. Dodatkowym argumentem było generowanie w teorii przestrzennie ciągłej członu $(\nabla \phi)^{2}$, który jest niezbędny do opisu nieliniowych fal w ośrodkach samo-oscylujących.

Rzeczywiście, podstawiając rozwiązania zsynchronizowane $\theta_{i}(t)=\Omega t+\phi_{i}$ do równania (3.1), dostaje się

$$
\omega_{i}-\frac{k}{2}\left(\sin \left(\phi_{i}-\phi_{i-1}+\alpha\right)+\sin \left(\phi_{i}-\phi_{i+1}+\alpha\right)\right)=\Omega \quad, i=1,2, \ldots, N \quad,
$$

co po zsumowaniu prowadzi do zsynchronizowanej częstości zależnej od $\alpha$

$$
\Omega=\frac{1}{N} \sum_{i=1}^{N} \omega_{i}-k \sin (\alpha) \frac{1}{N} \sum_{i=1}^{N} \cos \left(\phi_{i}-\phi_{i-1}\right) .
$$

Aby zrozumieć problem dynamiki tego układu, wyobrazić sobie można oscylatory $i-1, i, i+1$ o fazach $\theta_{i-1}(t)<\theta_{i}(t)<\theta_{i+1}(t)$. Oscylator $i$ widzi wtedy sąsiada $i-1$, jakby ten był od niego dalej o $\alpha \mathrm{w}$ sensie różnicy faz, natomiast sąsiada $i+1$, jakby ów był bliżej. Jednak odwrotnie widzi sąsiada $i$ oscylator $i+1$ (jakby był dalej) i $i-1$ (jakby był bliżej), co wprowadza pewne konkurujące oddziaływania - stąd przyjęło się nazywać to sprzężenie asymetrycznym. 
Ponieważ nie da się już zapisać układu (3.2) w postaci równania liniowego, znajdywanie rozwiązań jest trudne. Dlatego najpierw opiszemy, jak wygląda stabilność rozwiązań w ogólności, a następnie spróbujemy skonstruować pewne szczególne rozwiązania.

\subsection{Stabilność}

Rozważanie prowadzimy jak wcześniej: niech $\left\{\theta_{i}(t)\right\}_{i=1}^{N}=\left\{\Omega t+\phi_{i}\right\}_{i=1}^{N}$ będzie rozwiązaniem (3.1). Zaburzamy je: $\forall i: \theta_{i}(t) \rightarrow \theta_{i}(t)+u_{i}(t)$, gdzie $\left|u_{i}(t)\right| \ll 1$ i podstawiamy do (3.1). Po rozwinięciu do pierwszego rzędu względem $u_{i}$ otrzymujemy:

$$
u \simeq-\frac{k}{2}\left[\begin{array}{ccccc}
c_{1}^{\prime}+c_{2} & -c_{2} & & & -c_{1}^{\prime} \\
-c_{2}^{\prime} & c_{2}^{\prime}+c_{3} & -c_{3} & & \\
& -c_{3}^{\prime} & c_{3}^{\prime}+c_{4} & -c_{4} & \\
& \ddots & \ddots & \ddots & \\
& & -c_{N-1}^{\prime} & c_{N-1}^{\prime}+c_{N} & -c_{N} \\
-c_{1} & & & -c_{N}^{\prime} & c_{N}^{\prime}+c_{1}
\end{array}\right] u
$$

gdzie $u=\left[u_{1}(t), u_{2}(t), \ldots, u_{N}(t)\right]^{T}, c_{i}^{\prime}=\cos \left(\phi_{i}-\phi_{i-1}+\alpha\right), c_{i}=\cos \left(\phi_{i-1}-\phi_{i}+\alpha\right)$.

Widać, że ze względu na $\alpha$, która łamie parzystość cosinusów, $c_{i}$ i $c_{i}^{\prime}$ w ogólności nie są sobie równe, jak dla przypadku $\alpha=0$. Z tego względu m.in. macierz przestaje być cykliczna.

Korzystając z tw. Gerszgorina, analogicznie, jak w przypadku $\alpha=0$ (przy czym promienie kół sumuję po wierszach; sumowanie po kolumnach daje inne warunki, lecz nie dają one użytecznych szacowań), otrzymuje się:

(i) $\forall i: c_{i}>0 \wedge c_{i}^{\prime}>0$, czyli

$$
\forall i:\left\{\begin{array}{l}
\left|\phi_{i}-\phi_{i-1}+\alpha\right|<\pi / 2 \\
\left|\phi_{i-1}-\phi_{i}+\alpha\right|<\pi / 2
\end{array}\right.
$$

$\Rightarrow$ rozwiązania są na pewno stabilne.

(ii) $\forall i: c_{i}<0 \wedge c_{i}^{\prime}<0$, czyli

$$
\forall i: \begin{cases}\left|\phi_{i}-\phi_{i-1}+\alpha\right| & >\pi / 2 \\ \left|\phi_{i-1}-\phi_{i}+\alpha\right| & >\pi / 2\end{cases}
$$

$\Rightarrow$ rozwiązania są na pewno niestabilne.

(iii) $\left(\exists i: c_{i}>0 \vee c_{i}^{\prime}>0\right) \wedge\left(\exists j: c_{j}<0 \vee c_{j}^{\prime}<0\right) \Rightarrow$ nie możemy wnioskować o stabilności rozwiązań. 
Warto zauważyć, że przez dodanie do argumentu cosinusów $\alpha$, nie są one już symetryczne ze względu na zmianę znaku, stąd podwójny, w porównaniu do poprzedniego wypadku, warunek. Przykładowo:

dla $\alpha=\pi / 4, \phi_{1}=2 \pi / 3, \phi_{2}=\pi / 4$ mamy $\left|\phi_{2}-\phi_{1}+\alpha\right|<\pi / 2$, ale $\left|\phi_{1}-\phi_{2}+\alpha\right|>\pi / 2$.

Możemy zapytać się, jak będzie się zmieniała ilość stanów stabilnych/niestabilnych dla $\alpha \in[0, \pi / 2]$. Widać, że liczba rozwiązań, o których wiemy z twierdzenia Gerszgorina, że są stabilne, będzie maleć do zera, gdy $\alpha \rightarrow \pi / 2$ :

$$
\phi_{i}-\phi_{i-1} \in(-\alpha-\pi / 2, \pi / 2-\alpha) \cap(\alpha-\pi / 2, \pi / 2+\alpha)=(-\pi / 2+\alpha, \pi / 2-\alpha)
$$

Podobnie liczba rozwiązań na pewno niestabilnych będzie zanikać przy $\alpha \rightarrow \pi / 2$ :

$$
\phi_{i}-\phi_{i-1} \in(-\pi,-\pi / 2-\alpha) \cup(\pi / 2+\alpha, \pi)
$$

Okazuje się jednak, że niekoniecznie to liczba rozwiązań stabilnych bądź niestabilnych maleje, ale przede wszystkim reguły wyprowadzone z tw. Gerszgorina dają coraz mniej informacji, gdy $\alpha$ rośnie. Przedstawia to rys.3.1 na przykładzie układu 3 oscylatorów, pokazujący obszary możliwych rozwiązań (czyli po prostu różnic fazowych), które są stabilne czy niestabilne. Widać, że pomimo istnienia sporych obszarów stabilności dla $\alpha>0$, tw. Gerszgorina ,zauważa” jedynie niewielką ich część, aż przy odpowiednio dużej $\alpha$ już nic nie można z niego wywnioskować, choć ciągle dostępne są pewne rozwiązania stabilne. Zatem nie tylko znajdywania rozwiązań, ale i analiza ich stabilności jest znacznie utrudniona w przypadku asymetrycznego sprzężenia.

\subsection{Przykład 1: zerowanie sprzężeń}

Spodziewamy się rozwiązania zadanego przez

$$
\forall i: \sin \left(\phi_{i}-\phi_{i-1}+\alpha\right)=\sin \left(\phi_{i}-\phi_{i+1}+\alpha\right)=0
$$

Prowadzi to do

$$
\begin{aligned}
& \phi_{i}-\phi_{i-1}+\alpha=l \pi \\
& \phi_{i}-\phi_{i+1}+\alpha=l^{\prime} \pi
\end{aligned}
$$

Żeby takie rozwiązanie nie było niestabilne, przynajmniej jedna z prawych stron musi być mniejsza od $\pi / 2$. Ustalmy więc $l=0, l^{\prime}=1$. Po przeindeksowaniu drugiej linijki (ponieważ $i$ jest dowolne) dostaje się

$$
\begin{aligned}
& \phi_{i}-\phi_{i-1}+\alpha=0 \\
& \phi_{i-1}-\phi_{i}+\alpha=\pi,
\end{aligned}
$$




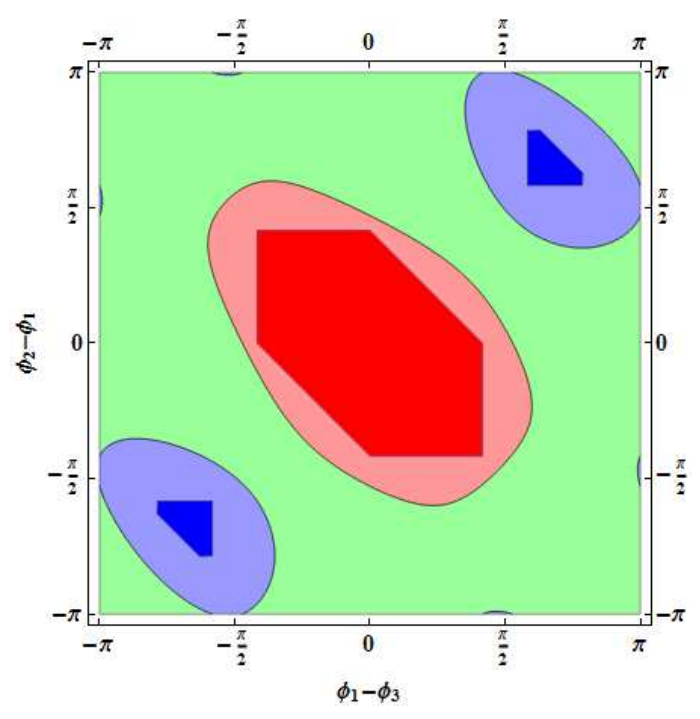

(a) $\alpha=\pi / 12$

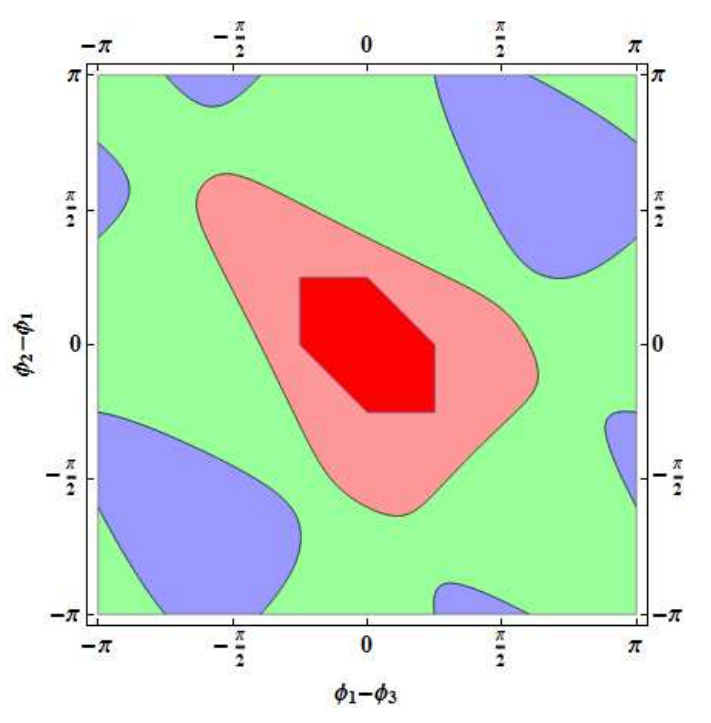

(b) $\alpha=\pi / 4$

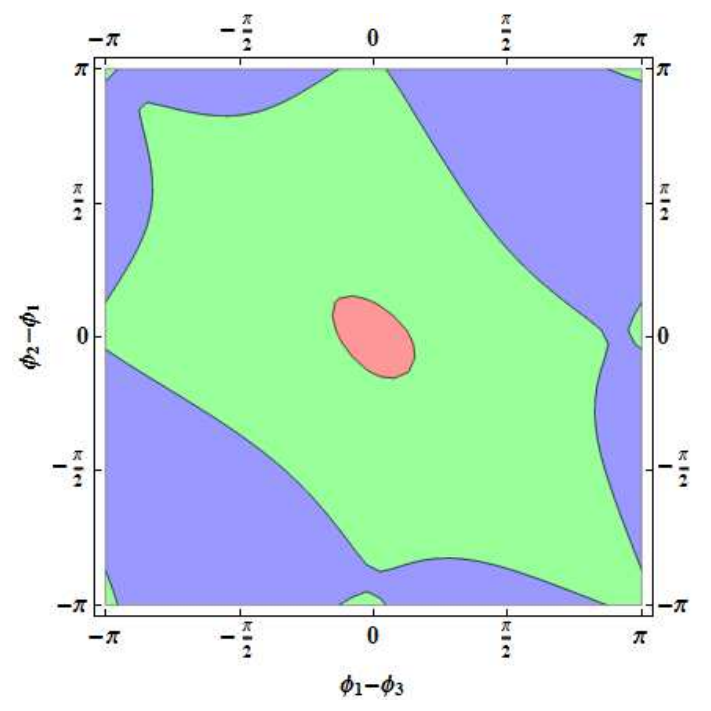

(c) $\alpha=\pi / 2.2$

Rysunek 3.1: Obszary stabilności rozwiązań dla $N=3$. Kolor czerwony to rozwiązania stabilne, niebieski i zielony - niestabilne odpowiednio ze względu na 2 i 1 wartość własną. Kolory ciemne to obszary wyznaczone przy pomocy tw. Gerszgorina. Wraz ze wzrostem stałej $\alpha$ twierdzenie to daje coraz mniej informacji. 
a więc możliwe jest tylko $\alpha=\pi / 2$. (Dla $l=l^{\prime}=0$ mamy rozwiązanie na pewno stabilne, ale wtedy oczywiście $\alpha=0$ i mamy układ całkowicie zsynchronizowany, z pełną koherencją faz, możliwy tylko dla rozkładu częstości $\omega_{i}=\Omega$ ).

Skoro został jedynie jeden przypadek, sprawdźmy stabilność bezpośrednim rachunkiem. Po wstawieniu różnic fazowych do macierzy zaburzenia mamy

$$
\dot{u} \simeq-\frac{k}{2}\left[\begin{array}{ccccc}
0 & 1 & & & -1 \\
-1 & 0 & 1 & & \\
& -1 & 0 & 1 & \\
& \ddots & \ddots & \ddots & \\
& & -1 & 0 & 1 \\
1 & & & -1 & 0
\end{array}\right] u
$$

Otrzymana macierz jest antysymetryczna, a dla takich zachodzi $\forall i: \operatorname{Re} \lambda_{i}=0$. Dostaliśmy więc rozwiązanie neutralnie stabilne postaci $\forall i: \phi_{i}-\phi_{i-1}=-\pi / 2$, dla którego $\Omega$ jest średnią częstości własnych, nawet więcej: $\forall i: \omega_{i}=\Omega$ (tzn. tylko taki rozkład może dojść do zadanego powyżej rozwiązania).

\subsection{Przykład 2: wzajemne znoszenie się sprzężeń}

Rozważamy przypadek, gdy

$$
\forall i: \sin \left(\phi_{i}-\phi_{i-1}+\alpha\right)=-\sin \left(\phi_{i}-\phi_{i+1}+\alpha\right)
$$

skąd oczywiście wynika, że $\Omega=\frac{1}{N} \sum_{i=1}^{N} \omega_{i}$.

$\mathrm{Z}$ tw. Gerszgorina wiemy, że rozwiązania będą stabilne, gdy

$$
\forall i:\left\{\begin{array}{l}
\left|\phi_{i}-\phi_{i-1}+\alpha\right|<\pi / 2 \\
\left|\phi_{i-1}-\phi_{i}+\alpha\right|<\pi / 2
\end{array} .\right.
$$

Możliwe jest również istnienie rozwiązań, gdy spełniony jest wariant (iii) tw. Gerszgorina, ale trzeba wtedy ,ręcznie” konstruować rozwiązanie i sprawdzać jego stabilność wstawiając do macierzy zaburzenia fazy i wyliczając wartości własne. Nie przeprowadzam tutaj takich rozważań.

Podany wyżej warunek prowadzi to do równości

$$
\forall i: \phi_{i}-\phi_{i-1}+\alpha=-\phi_{i}+\phi_{i+1}-\alpha
$$

i rzeczywiście po wstawieniu do macierzy zaburzenia mamy $c_{i}^{\prime}=c_{i+1}$, kolejne wiersze są proporcjonalne do $c_{i}^{\prime}$, co daje niedodatnie widmo wartości własnych, a więc stabilność. 
Jednakże z drugiej strony dostaliśmy równanie na różnice fazowe $\delta=\left[\delta_{1}, \delta_{2}, \ldots, \delta_{N}\right]^{T}$, (przy czym $\delta_{i}=\phi_{i}-\phi_{i-1}$, a $A$ ponawia oznaczenie z rozdz.1)

$$
A \delta=-2 \alpha e,
$$

które może zostać rozwiązane jedynie, gdy $-2 N \alpha=0$ (patrz Dodatek A). Widać więc, że nie dostajemy żadnego nietrywialnego rozwiązania dla $\alpha \neq 0$. 


\section{Rozdział 4}

\section{Sprzężenie modyfikowane,}

\section{symetryczne}

Okazuje się, że korzystając z wyników dla $\alpha=0$ można łatwo zanalizować podobny układ, zdefiniowany przez

$$
\dot{\theta}_{i}(t)=\omega_{i}-\frac{k}{2}\left[\sin \left(\theta_{i}(t)-\theta_{i-1}(t)-\alpha\right)+\sin \left(\theta_{i}(t)-\theta_{i+1}(t)+\alpha\right)\right] \quad, i=1, \ldots, N
$$

Charakteryzuje się on tym, że dla $\alpha>0$ może się synchronizować dla większych różnic fazowych pomiędzy oscylatorami. Patrząc na powyższe równanie, można powiedzieć, że każdy oscylator oddziałuje ze swoimi sąsiadami, jakby byli oni do niego bliżsi w fazie $o \alpha$.

Inaczej, punkt stacjonarny potencjału $-k \sin \left(\theta_{i}-\theta_{i-1}-\alpha\right)$ po prostu przesuwa się z różnicy faz równej 0 do równej $\alpha$. Ważne jest to, że kolejne oscylatory działają tu zgodnie, tzn. oscylator $i$ chce wyprzedzać $i-1$ o fazę $\alpha$, a oscylator $i-1$ chce o tyle się za sąsiadem $i$ spóźniać. W tym leży różnica w stosunku do wypadku opisanego w rozdz.3.

Podstawiając, jak wcześniej, $\theta_{i}(t)=\Omega t+\phi_{i}$ do równania (4.1), dostaje się analogicznie

$$
\omega_{i}-\frac{k}{2}\left(\sin \left(\phi_{i}-\phi_{i-1}-\alpha\right)+\sin \left(\phi_{i}-\phi_{i+1}+\alpha\right)\right)=\Omega
$$

przy $i=1,2, \ldots, N$. Widać, że zsumowanie tych równań znowu prowadzi do zsynchronizowanej częstości równej średniej częstości własnych

$$
\Omega=\frac{1}{N} \sum_{i=1}^{N} \omega_{i}
$$




\subsection{Warunki istnienia rozwiązań zsynchronizowanych}

W identyczny sposób da się zapisać równanie liniowe na sinusy różnic fazowych, które będą jednak przesunięte o $\alpha$. Równania (1.12) można odwikłać na dwa sposoby, przykładowo:

$$
\phi_{N}-\phi_{N-1}-\alpha= \begin{cases}\arcsin (p) & \in(-\pi / 2, \pi / 2] \\ -\arcsin (p)+\pi & \in(\pi / 2,3 \pi / 2]\end{cases}
$$

Zapisując wszystkie różnice faz według pierwszego sposobu, dostajemy układ dla rozwiązań stabilnych postaci

$$
\begin{aligned}
& \phi_{N}-\phi_{N-1}=\arcsin (p)+\alpha \\
& \phi_{N-1}-\phi_{N-2}= \arcsin \left(p+\frac{2}{k} \Delta_{N-1}\right)+\alpha \\
& \phi_{N-2}-\phi_{N-3}= \arcsin \left(p+\frac{2}{k} \Delta_{N-1}+\frac{2}{k} \Delta_{N-2}\right)+\alpha \\
& \vdots \\
& \phi_{1}-\phi_{N}=\arcsin \left(p+\frac{2}{k} \sum_{i=1}^{N-1} \Delta_{i}\right)+\alpha .
\end{aligned}
$$

Po zsumowaniu stronami, otrzymuje się warunek:

$$
\sum_{i=0}^{N-1} \arcsin \left(p+\frac{2}{k} \sum_{j=1}^{i} \Delta_{j}\right)=2 m \pi-N \alpha
$$

Jak wcześniej, należy sprawdzić $m$ równań, każde z nich ma co najwyżej jeden pierwiastek. Ilość nawinięć maksymalnie przebiega odpowiednio przesunięty zakres

$$
m=-\left\lfloor\frac{N}{4}\left(1-\frac{2 \alpha}{\pi}\right)\right\rfloor,-\left\lfloor\frac{N}{4}\left(1-\frac{2 \alpha}{\pi}\right)\right\rfloor+1, \ldots,-1,0,1, \ldots,\left\lfloor\frac{N}{4}\left(1+\frac{2 \alpha}{\pi}\right)\right\rfloor .
$$

Oznacza to, że maksymalnie można uzyskać $1+\left\lfloor\frac{N}{4}\left(1-\frac{2 \alpha}{\pi}\right)\right\rfloor+\left\lfloor\frac{N}{4}\left(1+\frac{2 \alpha}{\pi}\right)\right\rfloor$ różnych stabilnych rozwiązań. Jak widać, $\alpha \in[0, \pi / 2]$ przesuwa możliwe rozwiązania w stronę nawinięć wyższych tak, że przy $\alpha \rightarrow \pi / 2$ nie ma rozwiązań o $m<0$.

\subsection{Stabilność}

Analizę stabilności przeprowadza się analogicznie, jak dla $\alpha=0 \mathrm{w}$ rozdz.1.2, przy czym $c_{i}=\cos \left(\phi_{i-1}-\phi_{i}+\alpha\right)$. 
Z tw. Gerszgorina otrzymuje się klasyfikację

(i) $\forall i: c_{i}>0$ (czyli $\left.\forall i:\left|\phi_{i}-\phi_{i-1}-\alpha\right|<\pi / 2\right) \Rightarrow$ rozwiązania są na pewno stabilne

(ii) $\forall i: c_{i}<0\left(\right.$ czyli $\left.\forall i:\left|\phi_{i}-\phi_{i-1}-\alpha\right|>\pi / 2 \quad(\bmod 2 \pi)\right) \Rightarrow$ rozwiązania są na pewno niestabilne

(iii) $\exists i: c_{i}>0 \wedge \exists j: c_{j}<0 \Rightarrow$ nie możemy wnioskować o stabilności rozwiązań

Dla szczególnego przypadku $\forall i: c_{i}=0$ (czyli $\left.\forall i:\left|\phi_{i}-\phi_{i-1}-\alpha\right|=\pi / 2\right)$ rozwiązanie jest neutralnie stabilne.

Możemy zapytać się, jak będą się zmieniały stany stabilne/niestabilne w miarę przechodzenia od $\alpha=0$ do wyższych wartości z przedziału $\alpha \in[0, \pi / 2]$. Widać, że liczba potencjalnych rozwiązań, o których wiemy z twierdzenia Gerszgorina, że są stabilne, nie zmieni się:

$$
\phi_{i}-\phi_{i-1} \in(\alpha-\pi / 2, \pi / 2+\alpha)
$$

Podobnie liczba potencjalnych rozwiązań niestabilnych:

$$
\phi_{i}-\phi_{i-1} \in(-\pi, \alpha-\pi / 2) \cup(\pi / 2+\alpha, \pi) .
$$

Jednakże stabilne będą rozwiązania, których różnice fazowe będą większe, a więc nowe rozwiązania będą bardziej „rozsunięte” na okręgu i w efekcie będą musiały mieć większą liczbę nawinięć. Odpowiada to uwadze do zmodyfikowanego równania na istnienie rozwiązań (4.7), mówiącej, że przy rosnącej $\alpha$ znikają kolejne rozwiązania o ujemnych nawinięciach, a przybywa rozwiązań z $m>0$. 


\section{Podsumowanie}

W niniejszej pracy pokazaliśmy, że w modelu Kuramoto na sieci jednowymiarowej ze sprzężeniem lokalnym (najbliższych sąsiadów) synchronizacja może występować, choć jedynie w układach skończonych oraz dla pewnej klasy układów nieskończonych (które niestety eliminują losowość).

Rozwiązania zsynchronizowane zostały wyprowadzone jawnie, co więcej, z konstrukcji wynika ich stabilność. Okazuje się, że układ może dochodzić do dużej liczby (proporcjonalna do rozmiaru układu) różnych rozwiązań w zależności od warunków początkowych. Wydaje się, że przynajmniej część z nich jest marginalizowana, gdy układ (i liczba rozwiązań) rośnie, i jedynie niewielka ilość rozwiązań pozostaje z makroskopowymi basenami atrakcji.

W prosty sposób otrzymano dolne oszacowanie na krytyczną stałą sprzężenia $k_{c}$, dla której pojawia się jakiekolwiek rozwiązanie zsynchronizowane. Więcej, istnieje prosta metoda wyznaczania $k_{c}$ dla wszystkich istniejących rozwiązań.

Jak się również okazało, parametr porządku $r$ z modelu Kuramoto (tj. globalnego sprzężenia) nie łączy się zawsze z synchronizacją w modelu lokalnym. Występują rozwiązania zsynchronizowane (w sensie równych częstości oscylatorów, tzw. „phase-locking”), a nie wykazujące koherencji faz, którą wskazuje $r$.

Rozdziały 3 i 4 pokazują, że dodatkowe modyfikacje modelu można wprowadzać w ograniczonym stopniu. Szczególne trudności sprawia znajdowanie rozwiązań synchronizowanych w modelu asymetrycznego sprzężenia, dlatego próby ograniczono jedynie do sprawdzenia najprostszych przypadków. Model z modyfikowanym sprzężeniem symetrycznym uświadamia, że w prosty sposób można manipulować odległością (w sensie różnic fazowych) oddziaływania na siebie oscylatorów.

Mamy nadzieję, że przedstawione tu wyniki rzucą więcej światła na zachowanie układów lokalnie sprzężonych oscylatorów w większej ilości wymiarów. 


\section{Podziękowania}

Chciałbym złożyć serdeczne podziękowania promotorowi dr. hab. Pawłowi Górze - za kluczowe dla kształtu tej pracy pomysły i uwagi, a także za sprawowanie nade mną opieki naukowej na wcześniejszych latach studiów. Podziękowania należą się również prof. Lechowi Londze, który wskazał na problematykę synchronizacji na seminarium specjalizacyjnym.

Dziękuję również wszystkim Koleżankom i Kolegom ze studiów, za ich niejednokrotne cierpliwe objaśnienia i wspólny śmiech. Basi, za obecność i wsparcie, poświęcam myśli, które, gdy pisałem tę pracę, zalęgły się w bieli pomiędzy wierszami. Wdzięczność jestem również winien swojej Siostrze za żywe zainteresowanie moją ścieżką naukową i wiele cennych rad. Wreszcie chciałbym okazać szczerą wdzięczność Rodzicom, których roli w słowa ująć się nie da. 


\section{Dodatek A}

\section{Warunek rozwiazzania układu}

\section{liniowego}

Oznaczmy $\Delta_{i} \equiv\left(\omega_{i}-\Omega\right)$, wtedy równanie (1.5) przyjmuje postać

$$
\left[\begin{array}{rrrrr}
1 & -1 & & & \\
& 1 & -1 & & \\
& & \ddots & \ddots & \\
& & & 1 & -1 \\
-1 & & & & 1
\end{array}\right]\left[\begin{array}{c}
s_{1} \\
s_{2} \\
\vdots \\
s_{N-1} \\
s_{N}
\end{array}\right]=\frac{2}{k}\left[\begin{array}{l}
\Delta_{1} \\
\Delta_{2} \\
\vdots \\
\Delta_{N-1} \\
\Delta_{N}
\end{array}\right]
$$

Jeśli ma on mieć rozwiązanie, musi zachodzić $\operatorname{rank}(A \mid B)=\operatorname{rank}(A)=N-1$, gdzie $B$ jest wyrazem wolnym. Żeby rząd macierzy dołączonej był równy $N-1$, wystarczy sprawdzić, czy jest różny od $N$. Do tego wystarczy, by wyznaczniki macierzy stworzonych z dowolnych $N-1$ kolumn macierzy $A$ i wyrazu wolnego (pomijam w nim czynnik $\frac{2}{k}$ ) przyrównać do zera. 
Przykładowo, biorąc kolumny od 2 do $N$, mamy

$$
\begin{aligned}
& W_{1}=\operatorname{det}\left[\begin{array}{ccccc}
-1 & & & & \Delta_{1} \\
1 & -1 & & & \Delta_{2} \\
& \ddots & \ddots & \\
& & 1 & -1 & \Delta_{N-1} \\
& & & 1 & \Delta_{N}
\end{array}\right] \\
& =\Delta_{1}(-1)^{N+1} \cdot 1+(-1) \cdot(-1)^{1+1} \cdot \operatorname{det}\left[\begin{array}{cccc}
-1 & & & \Delta_{2} \\
\ddots & \ddots & \vdots \\
& 1 & -1 & \Delta_{N-1} \\
& & 1 & \Delta_{N}
\end{array}\right] \\
& =\Delta_{1}(-1)^{N}+(-1) \cdot W_{2},
\end{aligned}
$$

gdzie $W_{1}, W_{2}, \ldots, W_{N}$ to kolejne minory kątowe główne (poczynając od prawego dolnego rogu macierzy). Otrzymuje się stąd układ równań

$$
\begin{aligned}
W_{1} & =\Delta_{1}(-1)^{N+1}-W_{2} \\
W_{2} & =\Delta_{2}(-1)^{N}-W_{3} \\
\vdots & \\
W_{N-1} & =\Delta_{N-1}(-1)^{3}-W_{N} \\
W_{N} & =\Delta_{N}
\end{aligned}
$$

Po dodaniu stronami i przyrównaniu $W_{1}$ do zera dostaje się

$$
W_{1}=\Delta_{1}(-1)^{N+1}+\Delta_{2}(-1)^{N+1}+\ldots+\Delta_{N}(-1)^{N+1}=\sum_{i=1}^{N} \Delta_{i}=0
$$

co powtarza warunek (1.4) na to, że częstości własne oscylatorów mają średnią $\Omega$. Ze względu na cykliczną formę macierzy $A$ wyznaczniki innych kombinacji kolumn dają taki sam wynik. 


\section{Bibliografia}

[1] C.S. Peskin, Mathematical aspects of heart physiology, Courant Institute of Mathematical Sciences, New York, 1975.

[2] D.C. Michaels, E.P. Matyas, J. Jalife, Mechanisms of sinoatrial pacemaker synchronization: a new hypothesis, Circulation Res. 61, 704 (1987).

[3] N. E. Diamant, A. Bortoff, Nature of the intestinal slow-wave frequency, Am. J. Physiol. 216, 301 (1969).

[4] A. Sherman, J. Rinzel, J. Keizer, Emergence of organized bursting in clusters of pancreatic betacells by channel sharing, Biophys. J. 54, 411 (1988).

[5] A.K. Ghosh, B. Chance, E.K. Pye, Metabolic coupling and synchronization of NADH oscillations in yeast cell populations, Arch. Biochem. Biophys. 145, 319 (1971).

[6] J. Aldridge, E.K. Pye, Cell density dependence of oscillatory metabolism, Nature 259, 670 (1976).

[7] A.T. Winfree, The geometry of biological time, Springer-Verlag, Berlin-Heidelberg-New York, wyd. 2, 2000.

[8] J.L. Pruneda-Paz, G. Breton, A. Para, S.A. Key, A functional genomics approach reveals CHE as a component of the Arabidopsis circadian clock, Science 323, 1481 (2009).

[9] J. Buck, E. Buck, Synchronous fireflies, Scientific Am. 234, 74 (1976).

[10] J. Buck, Synchronous rhythmic flashing of fireflies. II., Quart. Rev. Biol. 63, 265 (1988).

[11] T.J. Walker, Acoustic synchrony: two mechanisms in the snowy tree cricket, Science 166, 891 (1969).

[12] Z. Néda, E. Ravasz, Y. Brechet, T. Vicsek, and A.-L. Barabási, Tumultuous applause can transform itself into waves of synchronized clapping, Nature 403, 849 (2000). 
[13] Z. Néda, E. Ravasz, Y. Brechet, T. Vicsek, and A.-L. Barabási, Physics of the rhythmic applause, Phys. Rev. E 61, 6987 (2000).

[14] Z. Jiang, M. McCall, Numerical simulation of a large number of coupled lasers, J. Opt. Soc. Am. 10, 155 (1993).

[15] S. Yu. Kourtchatov, V.V. Likhanskii, A.P. Napartovich, F.T. Arecchi, A. Lapucci, Theory of phase locking of globally coupled laser arrays, Phys. Rev. A 52, 4098 (1995).

[16] K. Wiesenfeld, P. Colet, S.H. Strogatz, Synchronization transitions in a disordered Josephson series array, Phys. Rev. Lett. 76, 404 (1996).

[17] K. Wiesenfeld, P. Colet, S.H. Strogatz, Frequency locking in Josephson arrays: Connection with the Kuramoto model, Phys. Rev. E 57, 1563 (1998).

[18] A.T. Winfree Biological rythms and the behaviour of populations of coupled oscillators, J. Theoret. Biol. 16, 15 (1967).

[19] H. Sakaguchi, Y. Kuramoto, A soluble active rotator model showing phase transitions via mutual entrainment, Prog. Theor. Phys. 76, 576 (1986).

[20] S.H. Strogatz, From Kuramoto to Crawford: exploring the onset of synchronization in populations of coupled oscillators Physica D 143, 1 (2000).

[21] B.C. Daniels, Synchronization of globally coupled nonlinear oscillators: the rich behaviour of the Kuramoto model, (2005).

[22] J.A. Acebrón, L.L. Bonilla, C.J. Perez Vincente, F. Ritort, R. Spigler, The Kuramoto model: $a$ simple paradigm for synchronization phenomena Rev. Mod. Phys. 77, 137 (2005).

[23] S.H. Strogatz, R.E. Mirollo, Collective synchronization in lattices of non-linear oscillators with randomness, J. Phys. A 21, L699 (1988).

[24] H. Sakaguchi, S. Shinomoto, Y. Kuramoto Local and global self-entrainments in oscillator lattices, Prog. Theor. Phys. 77, 1005 (1987).

[25] H. Daido, Lower critical dimension for populations of oscillators with randomly distributed frequencies: a renormalization-group analysis, Phys. Rev. Lett. 61, 231 (1988).

[26] J.J. Binney, N.J. Dowrick, A.J. Fisher, M.E.J. Newman, Zjawiska krytyczne: wstep do teorii grupy renormalizacji (PWN, Warszawa, 1998), s.76-78.

[27] A. Turowicz, Geometria zer wielomianów (PWN, Warszawa, 1967), s.50-52. 
[28] Z. Fortuna, B. Macukow, J. Wąsowski, Metody numeryczne (wyd. 5, WNT, Warszawa, 2001), s.256.

[29] Z.Zheng, G.Hu, B.Hu, Phase slips and phase synchronization of coupled oscillators, Phys. Rev. Lett. 81, 5318 (1998).

[30] Z.Zheng, G.Hu, B.Hu, Collective phase slips and phase synchronization in coupled oscillator systems, Phys. Rev. E 62, 402 (2000). 